\title{
The evolution of job stability and wages after the implementation of the Hartz reforms
}

\author{
Gianna C. Giannelli ${ }^{1,2}$ - Ursula Jaenichen ${ }^{3}$ Thomas Rothe ${ }^{3}$
}

Accepted: 1 August 2016 / Published online: 29 September 2016

(C) The Author(s) 2016. This article is available at SpringerLink with Open Access.

\begin{abstract}
We address the concerns about rising inequality in the German labour market after the implementation of the Hartz reforms between 2003 and 2005. We focus on the quality of new jobs started between 1998 and 2010 in West Germany in terms of job stability and level of earnings. Using social security data drawn from the Integrated Employment Biographies, we analyse the distributions of job durations and wages and model their determinants at the worker level. Our results show a high degree of job stability during and after the reform years, decreasing wage levels and increasing wage dispersion.
\end{abstract}

Keywords Hartz reforms - Job duration - Wage inequality

JEL classification $\mathrm{C} 34 \cdot \mathrm{C} 41 \cdot \mathrm{J} 31 \cdot \mathrm{J} 62 \cdot \mathrm{J} 68$

\section{Die Entwicklung von Beschäftigungsstabilität und Löhnen seit Einführung der Hartz-Reformen}

Zusammenfassung Seit den Hartz-Reformen in den Jahren 2003 bis 2005 gibt es Hinweise auf eine gestiegene Ungleichheit im deutschen Arbeitsmarkt. Anhand der Indikatoren Stabilität und Entlohnung untersuchen wir die Qualität von Beschäftigungsverhältnissen, die im Zeitraum von 1998 bis 2010 begonnen haben. Mit administrativen Daten aus den Integrierten Erwerbsbiographien analysieren wir

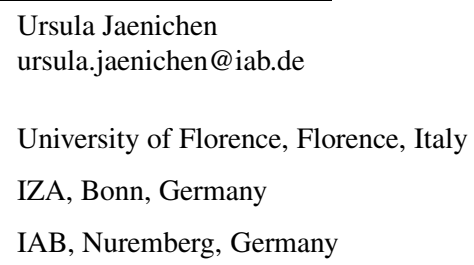

die Verteilungen und modellieren individuelle Determinanten von Beschäftigungsdauern und Löhnen. Die Ergebnisse weisen auf ein hohes Maß an Stabilität in den Beschäftigungsdauern, einen Rückgang des Lohnniveaus und einen Anstieg der Lohnungleichheit während und nach der Periode der Hartz-Reformen hin.

\section{Introduction}

The Hartz reforms were implemented from 2003 to 2005 after the so-called "placement scandal" of the Federal Employment Agency (Fleckenstein 2008). The aims of the Hartz reforms were to improve public employment services, enhance the efficiency of active labour market policies and decrease the number of unemployed persons in Germany. Among the reforms were the restructuring of the Federal Employment Agency, a reorganisation of the local employment agencies, and several minor legislative changes related to dismissal protection, fixed-term contracts and temporary agency work (see, e. g., Jacobi and Kluve 2007). The most important reform, Hartz IV, abolished the then-existing unemployment assistance for long-term unemployed workers and consolidated this program with social assistance for households in need, thereby worsening the conditions for a vast majority of longer-term unemployment benefit recipients.

In the years following the reforms, the labour market in Germany performed surprisingly well: from 2005 to 2008, unemployment decreased by one-third, while employment liable to social insurance increased by approximately the same amount (1.5 million persons, see Fig. 1). During

${ }^{1}$ See Goebel and Richter (2007) for an early analysis of changes in the available income of unemployment benefit recipients. 
Fig. 1 Number of Employed and Unemployed persons in Germany (Source: German Federal Employment Agency, quarterly average of monthly data, seasonally adjusted, own calculations)

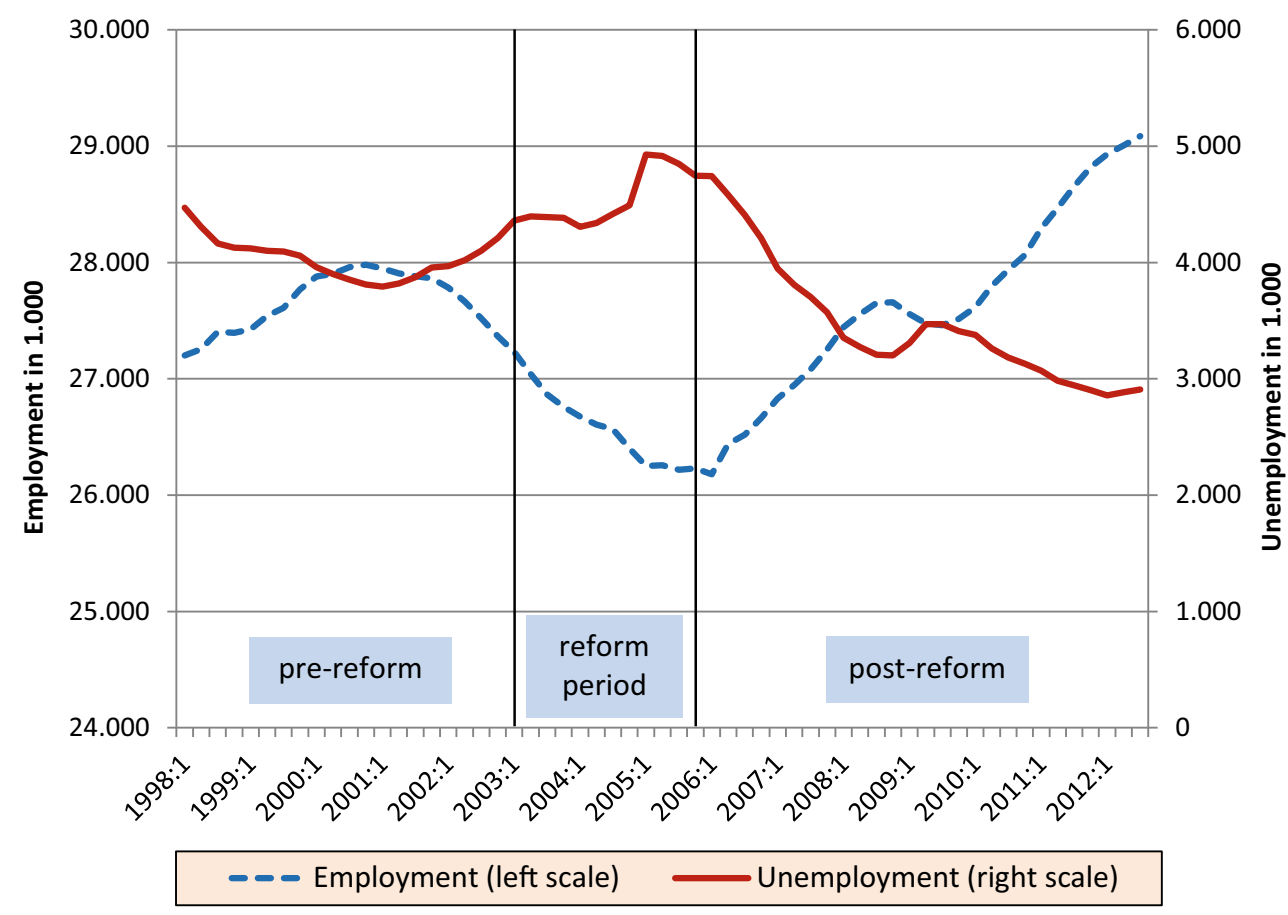

the recession years of 2008/2009, both the decrease in employment and the increase in unemployment were modest, although GDP decreased dramatically (see Fig. 2). This phenomenon was noticed worldwide, and Krugman even called it "Germany's job miracle". Nevertheless, there are concerns about rising wage inequality (Card et al. 2013) and the increasing prevalence of atypical and low-wage jobs (Eichhorst and Tobsch 2015), tendencies that may have laid the groundwork for the introduction of a general minimum wage in Germany in 2015.

This paper takes the positive overall performance of the German labour market following the Hartz reforms and during the great recession as a starting point for our analysis of whether there is an unsavoury side to this positive trend in the form of lower job quality. We use job duration and wages as indicators of job quality and look at new jobs started between 1998 and 2010 (the terms "job duration" and "job stability" are used as synonyms throughout the paper). We are interested in whether changes in job quality occurred in the "middle" of the labour market and therefore analyse the stability and wages of regular jobs covered by social security.

The quality of a specific job has various dimensions and many of them are difficult to measure. In addition to wages and stability, aspects such as mental and physical stress, autonomy and self-responsibility, temporary versus permanent contracts, working time, and the reconciliation of family and working life have been the subjects of research. ${ }^{2}$ The

${ }^{2}$ For an overview of several aspects of job quality, see Osterman (2013) and the literature cited therein. main reasons for our choice of indicators of job quality are that job stability and earnings are extremely important economically and that our data allow us to observe these indicators very precisely (limitations are discussed later in the paper).

The expectation that the Hartz reforms have increased inequality and created a generation of jobs that are lower paid and less stable than jobs in the past is supported by searchtheoretical arguments. Intensive monitoring and stricter use of sanctions will increase the job search intensity of unemployed workers. The worsening of conditions for unemployment benefit recipients will lead to lower reservation wages and increase the willingness of unemployed workers to accept jobs of a given quality. Rebien and Kettner (2011) report that after the reforms, job applicants more often accepted jobs with worse working conditions, e.g., longer commutes and even lower wages. In Sweden, Van den Berg and Vikström (2014) demonstrate that the use of sanctions induced unemployed job-seekers to take jobs with lower wages, fewer working hours and fewer qualification requirements.

The Hartz reforms also contained certain deregulative elements, such as a reduction of dismissal protection in small firms and a relaxation of the legislation on temporary agency work. The growing use of working contracts that offer less employment protection could be another source of the rising inequality in the labour market.

There are also good reasons to expect positive effects of labour market reforms on job quality. The matching of unemployed workers to jobs may have been positively influenced by the reorganisation of local employment agencies 
Fig. 2 Hiring and Separation Rates over the Business Cycle (Source: Quarterly hiring rate [hirings(t)/employment $(\mathrm{t}-1)]$ and separation rate [separations $(\mathrm{t}) /$ employment $(\mathrm{t}-1)]$ are calculated using official data of the German Federal Employment Agency. GDP is provided by the Federal Statistical Office)

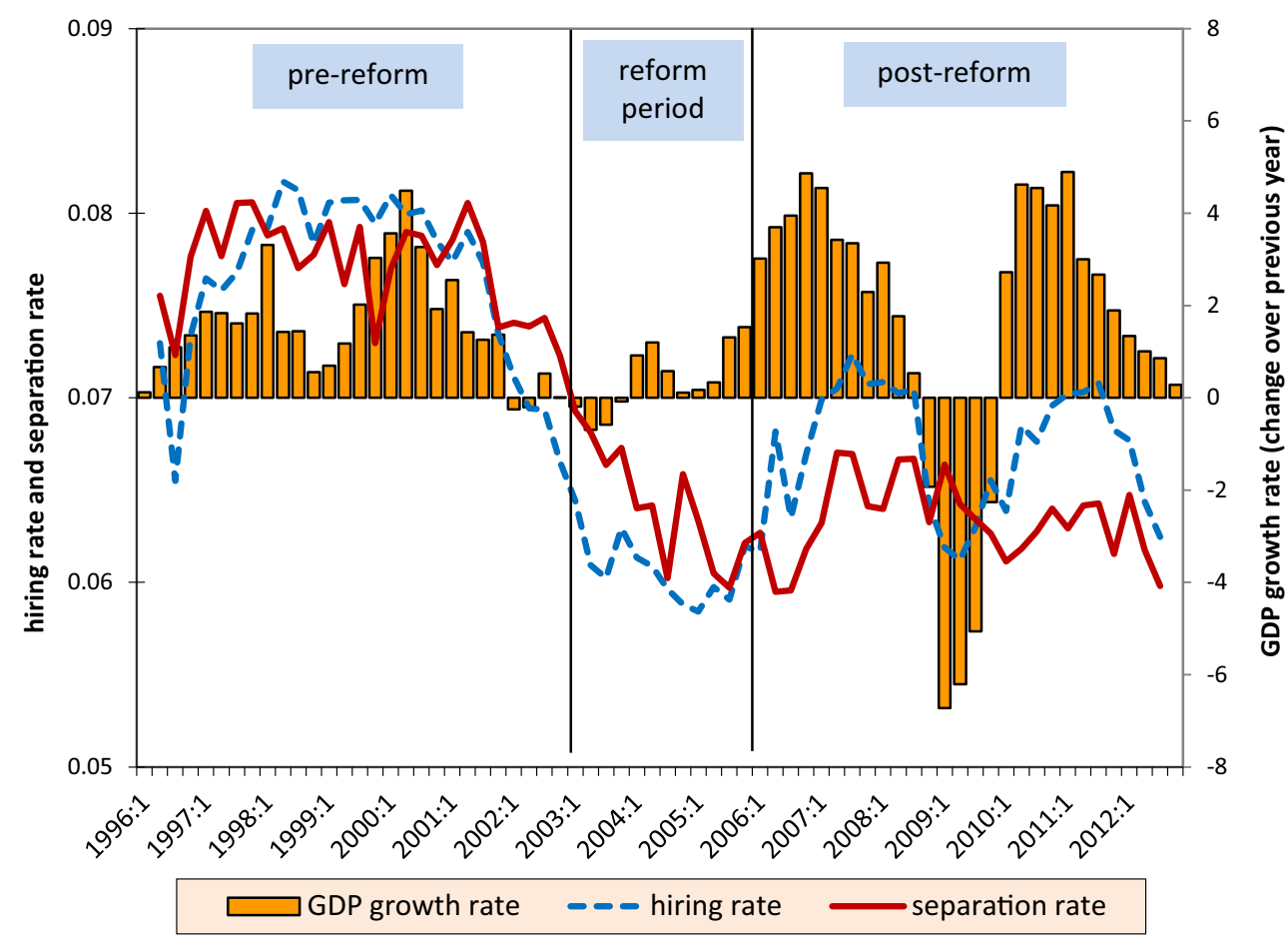

combined with the tightening of active labour market policies. Even if increased pressure on unemployed job-seekers will induce them to accept worse jobs in the first round, accepting these jobs might result in shorter unemployment durations, less depreciation of human capital, less stigmatisation and better signals to firms in the second round. ${ }^{3}$ Similarly, atypical jobs may become stepping stones into permanent and better-paid jobs in the medium run. ${ }^{4}$ All in all, it is an empirical question whether the Hartz reforms have had a positive or a negative influence on job quality.

It should be noted that the extent to which the Hartz reforms have influenced the German labour market is controversial. In a recent and prominent paper, Dustmann et al. (2014) argue that the scale of the Hartz reforms was not sufficiently large to substantially contribute to the positive changes in competitiveness and unemployment observed after the reform period. These authors stress the importance of factors such as flexibility in the German wage-setting institutions and the growing importance of firm-level negotiation of wages since the restructuring of the German economy after reunification. However, another view is that the Hartz reforms and "especially the merger between unemployment assistance and welfare, deeply changed the fun-

\footnotetext{
${ }^{3}$ Nekoei and Weber (2015) and Schmieder et al. (2016) discuss the effect of extending benefit entitlement periods and highlight the impact of non-employment duration on wages.

${ }^{4}$ Research on previous (pre-Hartz) changes in the employment protection law yields mixed results on dismissal probabilities and job stability (Bauer et al. 2007; Boockmann et al. 2008).
}

damental labor market institutions" (Möller 2015, p. 164). Similarly, the reduced generosity of the unemployment benefit system as a result of the Hartz reforms is considered a key determinant of the wage moderation during the years preceding the great recession (Gartner and Merkl 2011).

Although we share the view that the Hartz reforms had an important influence on the German labour market, we do not aim to estimate the size of this impact or to disentangle it from other factors that have contributed to the positive labour market outcomes observed in recent years. Our results on job durations and wages are descriptive in character; nevertheless, we will also perform econometric model analyses that account for worker and job heterogeneity.

We contribute new evidence to previous research in several ways. First, whereas existing studies have focussed primarily on wages, we analyse both wages and job duration because both aspects are fundamental dimensions of job quality. Second, a distinctive feature of our analysis is that we select cohorts of newly started jobs. We expect the employment contracts of workers taking new jobs to respond immediately to changes in both legislation and market conditions. Third, we update the evidence through 2010, giving us a period of analysis that allows us to consider a sufficiently long time span (five years) after the Hartz reforms.

The paper is organized as follows. In Sect. 2, we review the literature on job stability and wages in Germany. In Sect. 3, we describe our empirical strategy, and in Sect. 4, 
we present the results. The paper ends with concluding remarks.

\section{The Hartz reforms and recent trends in job stability and wages in Germany: a review of the literature}

There are several macro-level studies analysing the influence of the Hartz reforms on aggregate matching efficiency. Fahr and Sunde (2009) estimate positive effects of the first two reform packages (which addressed the organisation of the Federal Employment Agency and local employment agencies) on both the duration of unemployment and the matching probability. Subsequent aggregate studies confirm the improved matching efficiency following the implementation of the Hartz reforms (Hertweck and Sigrist 2013) and the increase in job-finding rates, not only for the shortterm unemployed but also for the long-term unemployed (Klinger and Rothe 2012). Launov and Wälde (2016) analyse the impact of different elements of the Hartz reforms using structural equilibrium models. Comparing pre- and post-reform steady states, the estimated effect of the reform of the public employment agencies in Germany accounts for approximately $20 \%$ of the reduction in equilibrium unemployment, whereas the Hartz IV reform accounts for another $5 \%$. Taken together, these studies confirm that that the functioning of the German labour market improved after the reforms. The reform of the benefit system through the Hartz IV reform seems to be of minor importance in the macroeconomic context.

The cyclical behaviour of aggregate labour turnover in Germany gives a first impression of whether jobs have become more or less stable since the mid-nineties (Rothe 2009). Fig. 2 shows the overall trends in hiring and separation rates over the business cycle between 1996 and 2012. Beginning with the year 2001, both rates clearly drop and continue to decrease during the period of the Hartz reforms. Remarkably, both hiring and separation rates remain fairly low during the cyclical upturn following the Hartz reforms (instead of returning to higher levels) and in the recession years 2008 and 2009. Thus, there has been a reduction in worker turnover in Germany that started before the Hartz reforms and continued thereafter. If job stability had decreased significantly after the reform period, we would have expected to see a corresponding increase in the turnover rates. This first piece of evidence will be confirmed and complemented by analyses that account for job heterogeneity in our micro-level analysis.

Regarding existing micro-evidence for Germany, there are studies that should be mentioned even if most of them do not refer to the Hartz reforms. These studies look at long-term trends in job stability or wages, and several of them focus explicitly on inequality and the processes of sorting or polarization in the labour market. ${ }^{5}$

Most analyses of long-term trends in individual job duration indicate a constant or declining level of job stability. Bergemann and Mertens (2011) find a tendency towards shorter job durations for the period 1984 to 1998, but other studies present evidence of a rather constant level of job stability until the middle of the last decade (Giannelli et al. 2012; Rhein 2010). Giesecke and Heisig (2011) look at the long period from 1984 to 2008 and thus cover the first years after the Hartz reforms. They find that overall mobility between firms has remained fairly constant, whereas less qualified workers have experienced a decline in job stability over time.

Boockmann and Steffes (2010) focus on the determinants of job duration in Germany and demonstrate that in addition to the socio-economic characteristics of workers, the internal structure of firms, as captured by the existence of working councils or further training opportunities, contributes to longer job duration. Furthermore, the results suggest a sorting process of workers with higher expected duration to firms offering more stable employment.

The recent literature on wages contains influential contributions that demonstrate a rise in wage dispersion in West Germany over the last several decades. Dustmann et al. (2009) focus on wages between 1975 and 2004 and document that inequality has continued to rise since the 1980s. In the 1980s, it was mainly the upper half of the wage distribution that was affected, but in the early 1990s, inequality also started to increase at the bottom half of the wage distribution. Antonczyk et al. (2010) find particularly pronounced growth of wage inequality at the bottom of the wage distribution from 2001 to 2006. Card et al. (2013) look at full-time workers in the years from 1985 to 2009 in West Germany and demonstrate that increased heterogeneity in the establishment component of wages strongly contributes to the rise in wage inequality. They also find evidence that (positive) assortative matching has increased, with workers' wage potential being more closely correlated with firms' wage premia over time. Cornelißen and Hübler (2011) estimate the influence of unobserved individual and firm heterogeneity on wage and job-duration functions using German linked employer-employee data for the years 1996 to 2002. Somewhat at odds with the results of Card et al. (2013), the estimated individual and firm effects

\footnotetext{
5 In the international literature, Gottschalk and Moffitt (1999) provide an overview of early research on job instability in the US during the 1980s and 1990s. Booth et al. (1999) examine job mobility and job duration over the period 1915 to 1990 in the UK. Autor et al. (2006, 2008) and Goos and Manning (2007) are examples of recent efforts to study wage inequality and job polarization in the US and the UK. Goos et al. (2009) provide evidence of disproportionate increases in both high-paid and low-paid employment in 16 European countries.
} 
show that high-wage workers tend to be stable workers and are more likely to be employed in low-wage firms, whereas low-wage workers are more likely to accept jobs with shorter durations in high-wage firms. ${ }^{6}$

The study of Riphahn and Schnitzlein (2016) analyses individual wage mobility, i.e., the probability of shifting to a different quantile of the wage distribution or changes in the rank positions, and shows a substantial decline in wage mobility over time. The results are provided for East Germany, where the decline in wage mobility begins in the early 1990s, and for West Germany, where decreasing wage mobility has been observed since the late 1990s.

The paper by Arent and Nagl (2013) is relevant because it claims to estimate the effect of the Hartz reforms on wages. Their central result, a structural break in the wage equation in the year of the benefit reforms, differs from the findings mentioned above and from ours (we find that wages started to decrease before 2005; see also Ludsteck and Seth (2014) for a comment).

Our empirical analysis borrows from the literature discussed in this section, especially when we present evidence on empirical distributions and in the specification of our models of job durations and wages. Although the sorting of workers to firms seems to be a promising road for further research, the results of these studies are not unambiguous. Our own analyses are performed at the individual or job level, which seems to be adequate for our research question. Our aim is to assess the changes in job quality after the implementation of labour market reforms that apparently improved the functioning of the labour market and led to the creation of new jobs. We use stability and wages as indicators of job quality and analyse them for a large share of the labour market.

\section{Empirical strategy}

We start our analysis with an assessment of overall trends in the distributions of job durations and wages. We then estimate job duration and wage models to determine the size and direction of changes in job quality across the reform period while controlling for the heterogeneity of jobs and workers. Finally, we look at the job quality over time of three groups of disadvantaged workers, namely, unskilled workers, previously unemployed workers and temporary agency workers.

Following a relevant strand of the economic literature, we measure job quality by the level of wages and by job

\footnotetext{
${ }^{6}$ A possible explanation for this puzzle, at least for large firms, might be that stable firms tend to be low-wage firms and high-wage workers can afford to buy job security by choosing permanent and long-lasting jobs in those stable firms (Cornelißen and Hüber 2011).
}

duration: the higher the wage is, the better the job is; the longer a job lasts, the better the job is (Jahn and Rosholm 2014 or Caliendo et al. 2013).

We use a flow sampling approach and select cohorts of jobs starting in the same year or period. This approach avoids oversampling of longer durations, known as lengthbias (Cameron and Trivedi 2005). A drawback of this approach is that our sampling yields a large share of incomplete job spells because of the limited observation period. Because we also censor jobs after 24 months, our analysis of changes in survival probabilities and job-leaving hazards over time is confined to changes in the initial two years in a job and is based on samples with large numbers of censored job spells.

We examine entry wages (wages at the time of the first notification of a worker with a specific employer), which ensures that we do not mix wages for new jobs with the wages of incumbent workers who have already gained some experience on the job. Because new jobs will strongly reflect current labour market conditions, changes in the market wage or an increase in temporary, unstable jobs will be revealed rather quickly in our samples. With respect to wages, we see our analyses as complementing other studies based on stock samples.

\subsection{The job duration model}

To analyse job durations, we estimate the following piecewise exponential mixed proportional hazard model (Blossfeld et al. 2007; Cameron and Trivedi 2005; Gutierrez 2002):

$$
\begin{aligned}
& \lambda_{i j}\left(t \mid x_{i}^{\prime} \beta, v_{i}\right)=\lambda_{0}(t) \exp \left(x_{i}^{\prime} \beta\right) v_{i}, \\
& i=1, \ldots, N ; j=1, \ldots, J
\end{aligned}
$$

and

$$
\lambda_{0}(t)=\lambda_{j}, \tau_{j-1}<t<\tau_{j}
$$

where $\lambda_{i j}$ is the hazard rate representing the risk of leaving

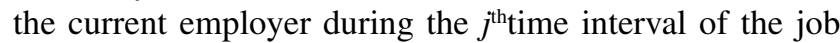
spell belonging to individual $i$. Job durations are split into at most $J$ time intervals (pieces) to model changes in the risk of job termination conditional on the time already spent in the current job. The $j$ th interval starts at duration $\tau_{j-1}$ and ends at duration $\tau_{j}$. The baseline hazard $\lambda_{0}(t)$ is a step function that is constant within intervals. Unobserved heterogeneity is modelled by a gamma-distributed frailty term $v_{i}$ that is assumed to be specific to the job spell. Only the variance $\theta$ of the frailty term is estimated.

The vector $x_{i}$ is a set of individual, job, firm, industry, and macroeconomic time invariant explanatory variables 
that are specific for an individual at the beginning of the job.

\subsection{The wage model}

To analyse wages, we estimate censored regression models that allow us to take the threshold for social security contributions into account (Cameron and Trivedi 2005).

We model the observed censored wage $W_{i j}$ of individual $i$ in year $j$ as the realization of a latent variable $W_{i j}^{*}$ :

$W_{i j}^{*}=x_{i j}^{\prime} \beta+\varepsilon_{i}$

where $x_{i j}$ are the covariates of individual $i$ if her employment spell starts in year $j$, and $\varepsilon_{i}$ is a normally distributed error term with variance $\sigma^{2}$.

The observed wage is:

$W_{i j}=\left\{\begin{array}{c}W_{i j}^{*} \\ c_{j}\end{array}\right.$ if $\frac{W_{i j}<c_{j}}{W_{i j} \geq c_{j}}$

where $c_{\mathrm{j}}$ is the threshold for social insurance contributions, which varies over time.

The coefficients $\beta$ measure the influence of the covariates on the latent variable $W_{i j}^{*}$. The maximum likelihood estimation yields results for the vector of coefficients as well as for the variance $\sigma^{2}$.

\subsection{Data and variables}

We draw our data from a two \% sample of the German Integrated Employment Biographies (IEB), a large administrative data set regularly produced at the Institute for Employment Research (IAB) in Nuremberg. ${ }^{7}$ The IEB contains employment liable to social insurance but does not include self-employment or civil servants. We focus on workers' employment spells and wages from 1998 to 2010.

The analysis will concentrate on West Germany which accounts for more than $80 \%$ of the German labour market. A common analysis for East and West is hindered by the large differences that continue to exist between the two labour markets. ${ }^{8}$ Selected results on overall trends in East Germany are contained in the appendix.

We select workers aged 25 to 54 when starting their jobs. Workers under 25 or over 54 are excluded because the job exits of younger workers often coincide with re-entry into the educational system and the transitions of older workers might be influenced by the alternative option of retirement.

\footnotetext{
7 See Jacobebbinghaus and Seth (2007) for a detailed description of an earlier version of the IEB Sample (IEBS).

${ }^{8}$ See Riphahn and Schnitzlein (2016) and Möller (2015) for a discussion of East-West differences in wage distribution.
}

Because our focus is on employment spells, we also exclude apprentices of any age.

The duration of a job is defined as a period of employment in the same establishment. ${ }^{9}$ Successive sub-spells within the same establishment are concatenated to generate the job spells, allowing for a maximum of 90 days of interruption. The start and end of the job spells are measured exactly in days. To keep the observation window as long as possible, we look at durations up to 24 months, therefore censoring longer job spells. In the case of overlapping job spells, we only keep the spell with the highest amount of earnings.

Entry wages are measured as those of the first sub-spell (lasting at most one year) contained in a possibly longer employment episode. We deflate the nominal amount with the German consumer price index to obtain the real daily wage. Right-censoring occurs at the threshold for social security contributions, which is adjusted almost every year. ${ }^{10}$ The exact amount of wages above the threshold is unobserved.

Even if the data allow us to distinguish between fulltime and part-time work, they do not contain information on hours worked. Consequently, although we include parttimers (those liable to social insurance) in the analysis of job durations, we are forced to exclude them from the analysis of wages, which implies the neglect of a considerable part of the female workforce. ${ }^{11}$ In addition, we exclude "mini-jobs" and other part-time jobs with short hours or low earnings from our analyses. Mini-jobs are legally required to fall below a certain threshold (e.g., $400 €$ in 2012) and are largely exempted from social security contributions. The growth of such jobs in recent years is certainly relevant to our research question (Jahn et al. 2012; Möller 2014). However, due to the lack of information on hours worked and because earnings from mini-jobs often constitute a type of extra income, these jobs are difficult to analyse without any information on the household context.

With respect to individual characteristics, the administrative data contain information on workers' age, gender and nationality. Information regarding workers' skill levels combines different types of school and university training

\footnotetext{
9 The employment information is based on firms' notifications to the social insurance agencies, which are obligatory at least once annually. Therefore, the employment period covered by a notification can last from a few days up to a maximum of one year.

${ }^{10}$ In 2010, the West German threshold was equal to 180.82 (5500) $€$ per day (month).

11 Moreover, there might still be part-time workers in our sample, because some of them might have been erroneously declared full-time workers. In fact, since 2011, the collection of information on working times in the employment statistics has changed. The break in the data caused by this change has revealed a considerable overestimation of the share of full-time workers before 2011 (Bundesagentur für Arbeit 2014).
} 
with a binary indicator of whether the worker has completed vocational training. We include indicators of labour market status preceding the new job, distinguishing "jobs taken after unemployment" (where unemployment is defined by benefit receipt or being registered with the local employment agency), "job-to-job changes" (allowing for 31 days of non-employment between jobs), "gaps" (periods without entries in our data) and "first spells", which are workers' first appearance in the IEB. Jobs with fixedterm contracts contribute to our results on durations and wages but cannot be distinguished from permanent jobs in our data. Regarding temporary agency work, the Hartz reforms implied a considerable liberalization and the increase in the number of temporary agency workers has been one of the main topics in the debate on recent labour market changes in Germany. In contrast to fixed-term contracts, temporary agency workers can be identified relatively well using the industry code (see Antoni and Jahn 2009).

We include industry and firm size class in our models as information on establishments. ${ }^{12}$ To take account of business cycle effects, we include indicators for the state of the local labour market: GDP growth obtained from the German Federal States' Accounts and the regional unemployment rate made available by the Federal Statistical Office, with both variables measured at the level of the West German districts (Kreise). Seasonal effects are modelled by the inclusion of dummy variables for the quarters of job entry.

In the analysis of overall trends in job quality, we focus on yearly cohorts of new jobs. In our regression models of job duration and wages, we group the observations into three sub-periods: jobs beginning in the period before the reforms (1998 to 2002), jobs beginning during the period of the Hartz reforms (2003 to 2005) and jobs beginning in the post-reform period (2006 to 2009/2010).

\section{Results}

We first discuss the results of the overall analysis of job duration and wages in new jobs (Sect. 4.1). We then turn to the model analysis (Sect. 4.2) and, finally, to the results concerning the three selected groups of disadvantaged workers: unskilled workers, temporary agency workers, and previously unemployed workers (Sect. 4.3).

\footnotetext{
12 Because of several changes in the classification system of industries, a combined 3-digit industry variable generated at IAB's Research Data Centre (see Eberle et al. 2011) is used and regrouped into broader categories for the regression analyses.
}

\subsection{Trends in the distributions of job durations and wages}

The duration of a new job is defined as an uninterrupted period of work with the same employer (see Sect. 3.3). We adopt Kaplan-Meier survival function estimators to plot time trends of the distributions of job durations. For wages, we compare the quartiles ( 25 th, median and 75 th percentile) of the distribution of log wages. To visualize broad group differences, we first distinguish by gender and then by skill level.

\subsubsection{Durations of newly started jobs}

Fig. 3 shows the estimated probabilities of staying in a job at specific durations after the job begins for job spells started between January 1998 and December 2009 (December 2008 for survival probabilities of 18 and 24 months).

Job stability is fairly high. The estimated 12-month survival probabilities for male workers are between 50 and $60 \%$, and they are even higher for female workers (see also Table 4 in the appendix). Over time, the survival probabilities for male workers seem to be fairly stable, whereas for female workers they show a tendency towards longer job durations. There is a temporary decrease in survival probabilities for jobs beginning in the year 2000; this decrease is more pronounced for women and for longer durations. We do not have a ready explanation for this result; ${ }^{13}$ in any case, the size of this reduction is rather limited (up to 4 percentage points for women's 24-month survival probability, see Table 4 in the appendix). ${ }^{14}$ Overall, the vertical distances between the survival probabilities at different durations remain fairly constant, meaning that within the groups of male and female workers, job durations do not become much more unevenly distributed over time (see also Fig. 7 in Sect. 4.3). As an intermediate result, there are no signs of a general downward trend in job durations during or after the reform period, which confirms the aggregated turnover rates presented in Fig. $2 .{ }^{15}$.

Fig. 4 distinguishes between three skill levels (see also Table 5 in the appendix). The category of "unskilled" workers comprises those with lower than medium education

\footnotetext{
13 If anything, the labour market reforms adopted in the period 1999-2001 went in the direction of re-regulation (see Giannelli et al. 2012).

14 The decrease in the 2009 survival probabilities for longer durations is due to the censoring of these spells at the end of 2010.

${ }^{15}$ In East Germany, the 6-month survival probabilities decrease somewhat over time, whereas longer-term survival probabilities remain constant or even increase. As a result, survival probabilities for jobs started in 2008/2009 in East Germany are more similar to those observed in West Germany than they were previously. See Fig. 8 and Table 4 in the appendix.
} 
Fig. 3 Job Survival Probabilities after $6,12,18$ and 24 Months. Survival probabilities at 18 and 24 months are not observed for jobs starting in 2009 (Source: IEB, own calculations, $N=816,774$ )

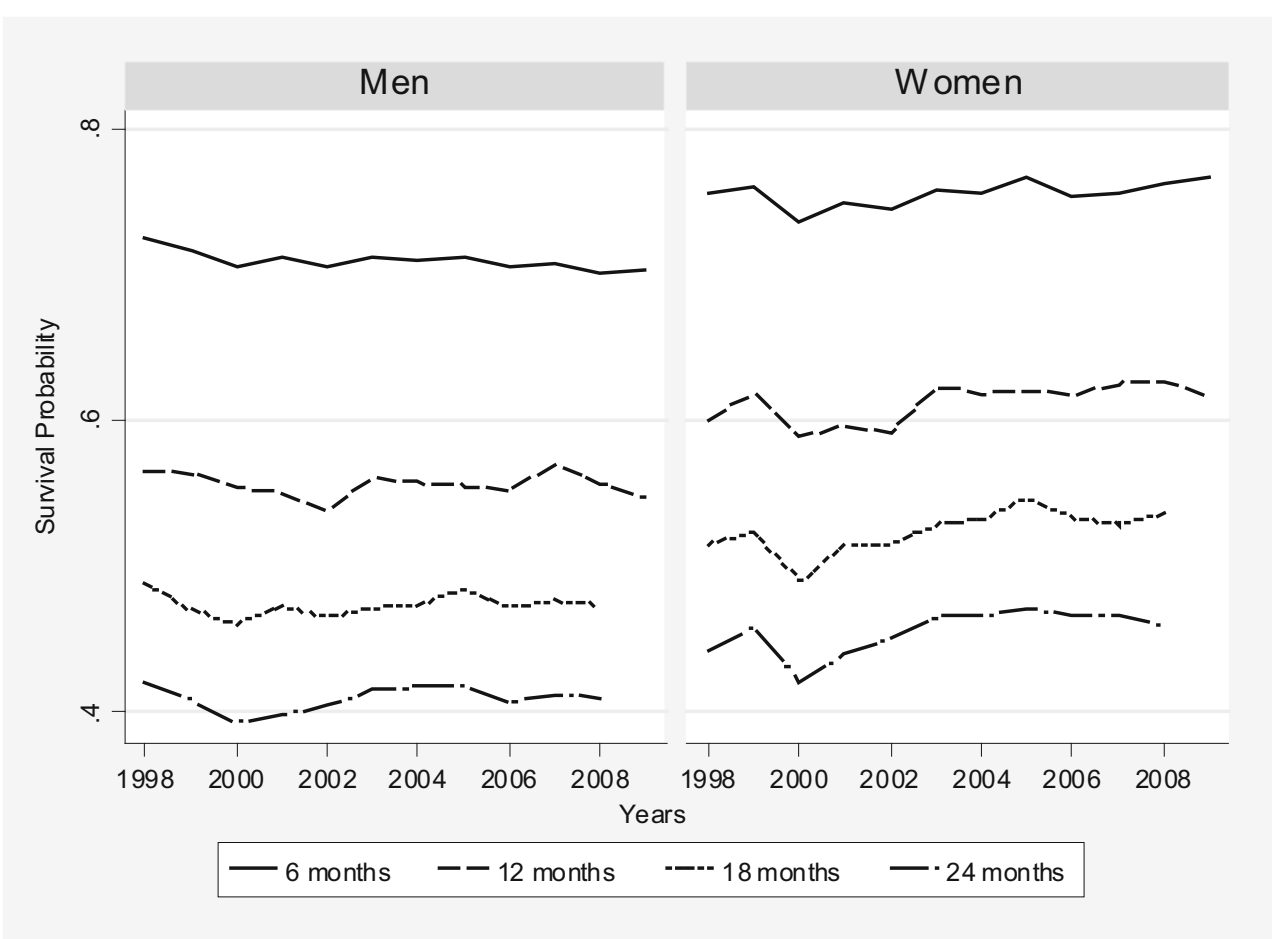

and without vocational training. The category of "skilled" workers includes workers with up to a medium level of education, workers with vocational training, and workers with a degree that qualifies them for professional college or university attendance. Workers in the "highly skilled" category have college or university degrees.

For a given duration, highly skilled workers have the highest survival probabilities, whereas unskilled workers have the lowest. Over time, the survival probabilities decrease somewhat for unskilled workers, especially at job durations of 18 and 24 months. The opposite is true for highly skilled workers; their survival probabilities show a slight upward trend, which is stronger for longer job durations. Because the observed changes are rather small, this evidence indicates that heterogeneity in job durations within skill groups has also not increased significantly over time.

\subsubsection{Wages in newly started jobs}

This analysis is confined to full-time workers, because information on hours worked is not available for part-time workers (see Sect. 3.3).

By now, the growth in earnings inequality over the last several decades and a steady decline in real wages since the early $2000 \mathrm{~s}$ is fairly well established for Germany, as well as for other industrialized countries (Dustmann et al. 2009, Card et al. 2013). With its focus on new jobs, our analysis presents further evidence on this issue.
The wage variable is measured as the log of daily real wages in 2005 prices. In Fig. 5, the 25th percentile, median, and 75th percentile of the wage distributions for men and women are plotted over the years (exact figures for the years 1998 and 2010 can be found in Table 6 in the appendix).

In line with the results of Card et al. (2013), the decrease in real wages after 2001 is clearly visible. For both men and women in new jobs, the decline in wages is strongest in the 25 th and 50th percentiles of the wage distribution, whereas the decline in the 75th percentiles is comparatively modest. Furthermore, wage inequality has been increasing among both men and women. The lower interquartile difference (50th percentile minus 25 th percentile) has increased by $8 \%$ for men and by $4 \%$ for women, and the upper interquartile difference (75th percentile minus 50th percentile) has increased by $6 \%$ for both men and women (Table 6). ${ }^{16}$

As previously noted, "wage moderation" is one potential explanation of Germany's relatively good employment performance during the great recession in 2008/2009. In accordance with most of the studies summarized in Sect. 2, our results show that the decrease in real wages begins well before the Hartz reforms. Thus, one impact of the reforms might have been to strengthen a pre-existing tendency towards lower wages. The size of wage losses in our sample

\footnotetext{
${ }^{16}$ For values up to 0.05 , the differences in log points are good approximations of percentage wage changes.
} 
Fig. 4 Job Survival Probabilities after $6,12,18$ and 24 Months, by Skill Level. Survival probabilities of 18 and 24 months are not observed for jobs starting in 2009. (Source: IEB, own calculations; $N=$ $816,774)$

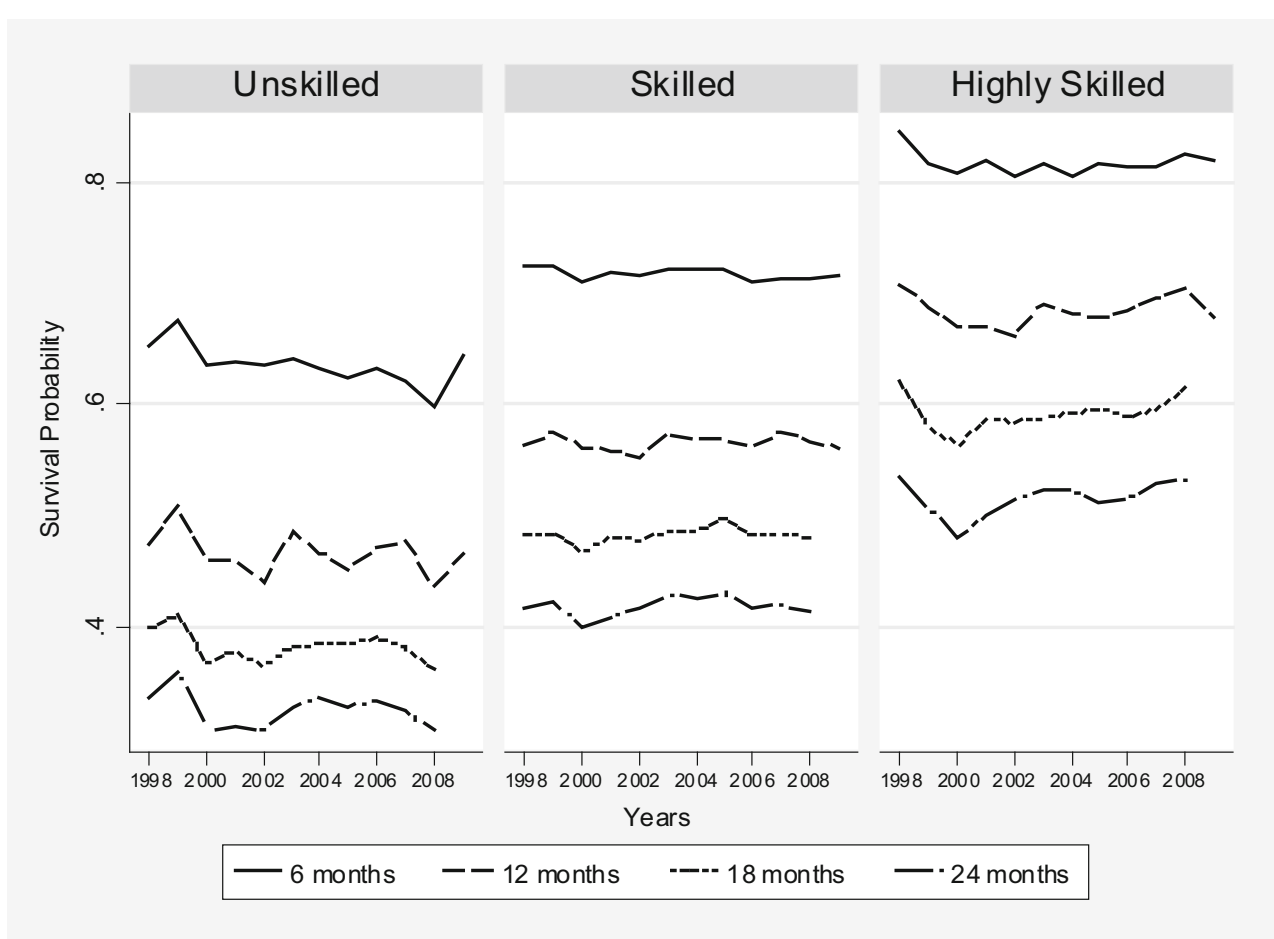

of new jobs is clearly larger than the wage decreases reported in Card et al. (2013). ${ }^{17}$

The differences in entry wages between skill levels are substantial (Fig. 6, Table 7 in the appendix). Furthermore, the disadvantage of unskilled workers is increasing. The median log wage of highly skilled workers, for example, decreased from 4.79 in 1998 to 4.63 in 2010, implying a daily wage loss of $15 \%$ (approximately $18 €$ ). The corresponding median wage loss for skilled workers from 1998 to 2010 was also $15 \%$ (10€). However, the median wage loss for unskilled workers was $21 \%$ (11 €; see Table 7). In addition, within-group inequality has been rising, which also accords with the results of Card et al. (2013). For the skilled and highly skilled worker groups, the decline in

\footnotetext{
17 The 1995-2009 wage decreases shown in Table 1 in Card et al. (2013) amount to -4 to $-6 \%$. Considering workers moving between different quartiles of the establishment wage distribution, the study also finds large wage decreases in certain cases, especially for the period 2002-2009 (see Card et al. 2013; Online Appendix Table 6).

18 For highly skilled workers, the 75th percentile is unfortunately not informative because for this group, between $17 \%$ (in 2010) and 29\%(in 1998) of workers have entry wages above the social security threshold.

19 Overall wage trends for East Germany are contained in the appendix, Fig. 9 and Table 6. In 2010, there remains a substantial gap between the levels of East German and West German wages. Wage dispersion in East Germany has increased over time and is larger for women than for men. The wage decrease in East Germany was largest in the lowest quartile and larger for men than for women in all three quartiles. In 2010, East German daily full-time wages at the 25th percentile were approximately $38 €$ for men and approximately $33 €$ for women.
}

wages is strongest in the 25 th percentile (that is, for workers with the lowest earnings in these groups). ${ }^{18} 19$

\subsection{Model analysis}

\subsubsection{Job duration}

Although no general tendency towards shorter job durations over time was revealed by the analysis in Sect. 4.1.1, we now consider the possibility that changes in the composition of jobs have influenced this result. We estimate a duration model that controls for a broad range of explanatory variables. The objective is to determine whether the period in which the Hartz reforms were implemented or the subsequent period are associated with changes in job durations when we take into account changes in the structure of jobs, as captured by our covariates. Because we do not use an experimental or quasi-experimental design, the estimated covariate effects reflect empirical associations rather than causal influences.

The model is a single spell model, estimated separately for men and women, for employment spells beginning between January 1998 and December 2008. For persons with

\footnotetext{
20 The selection of only one spell per person and the exclusion of spells starting in 2009 account for the different numbers of observations used for the graphical survival analysis in Section 4.1.1 and the model analysis in this section. The means of the model variables are contained in Table 8 in the appendix.
} 
Fig. 5 Distribution of Wages (Source: IEB, own calculations, $N=747,214)$

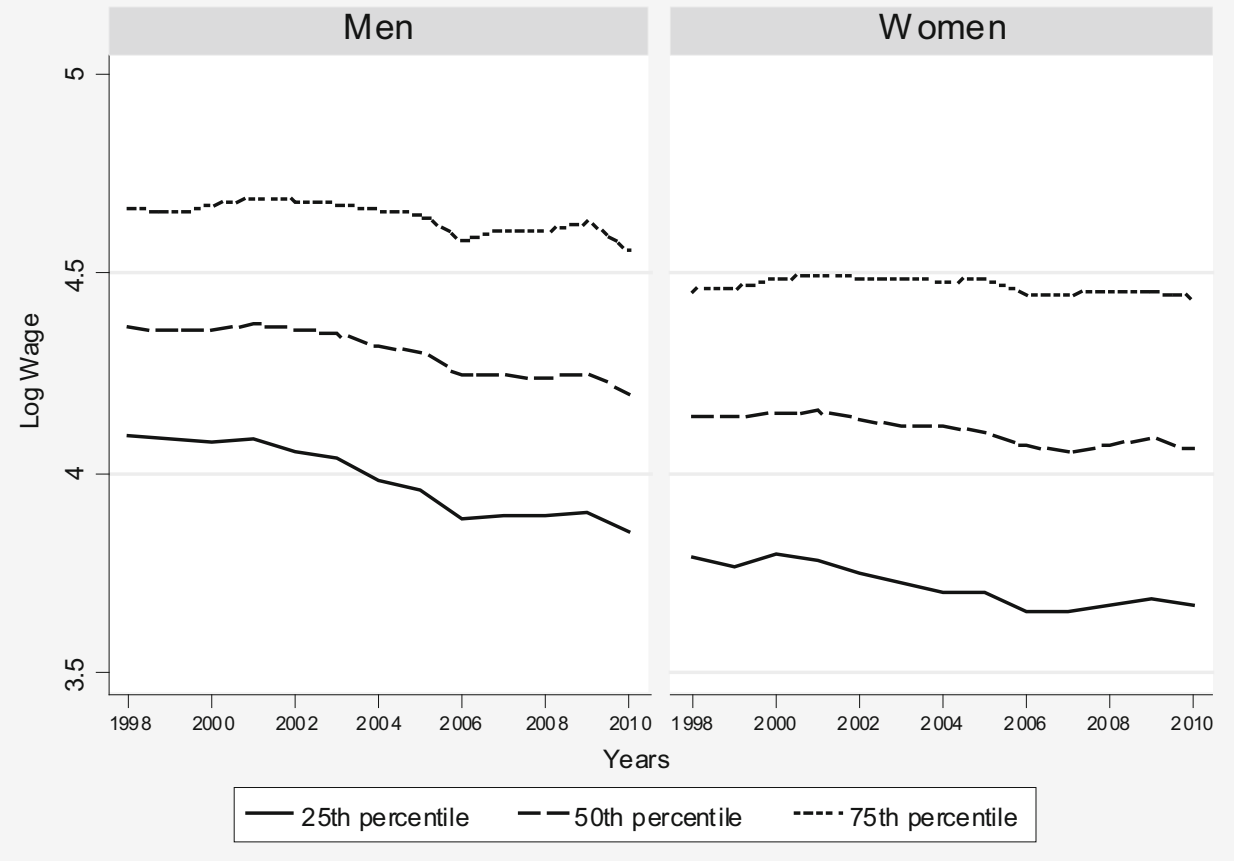

Fig. 6 Distribution of Wages by Skill Level (Source: IEB, own calculations, $N=747,214$ )

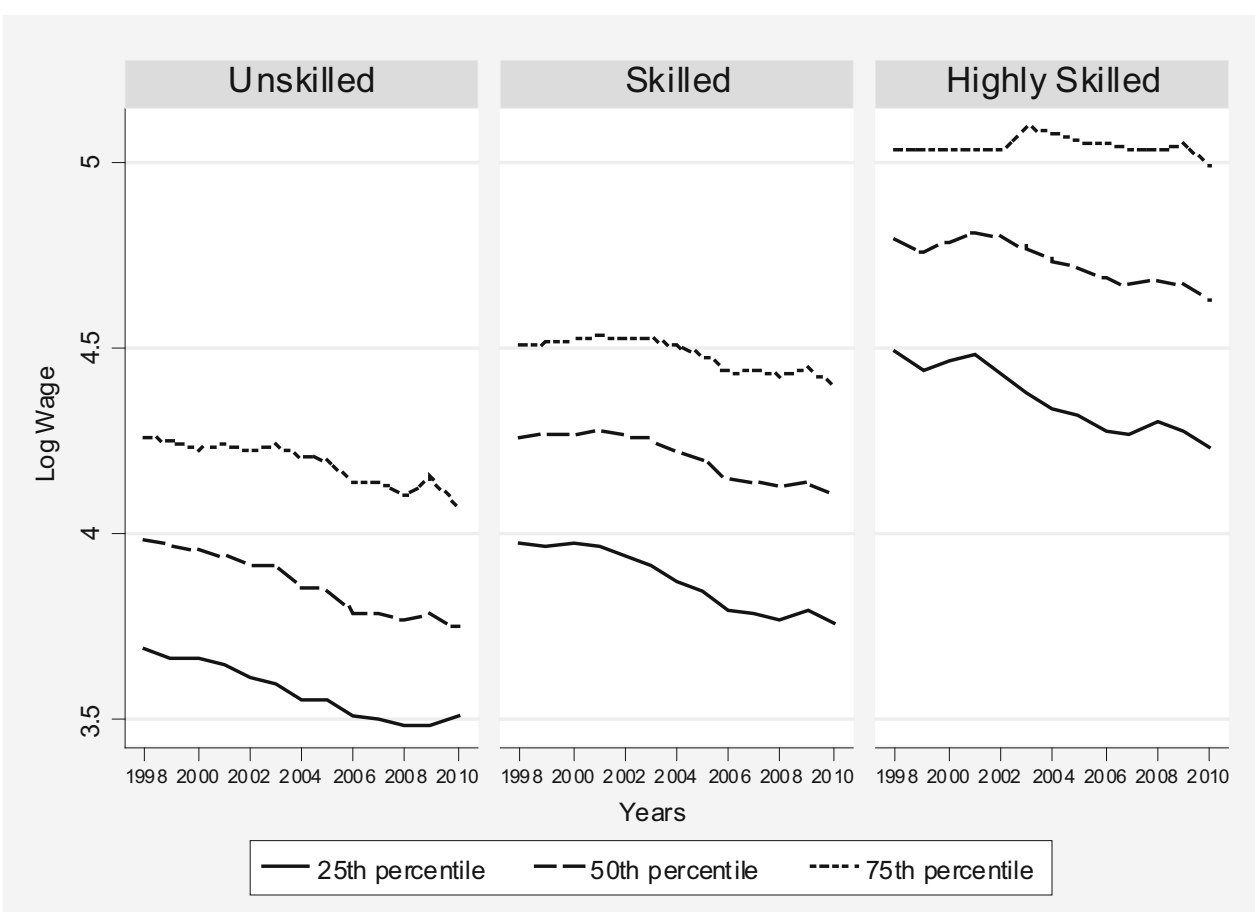

more than one new job in the observation window, we randomly select only one spell. ${ }^{20}$

The results are presented in the form of hazard ratios, which - in the case of binary or categorical variables indicate the influence of a variable on the risk of leaving the job relative to the reference group (see Table 1). The relationship between the risk of terminating a job and job duration is inverse, meaning that a value of the hazard ratio greater (smaller) than one implies a positive (negative) effect on the hazard and a negative (positive) effect on duration for that variable. The $\mathrm{z}$-values in Table 1 are based on the cluster-robust estimation of the variance-covariance matrix, because the district-level variables of unemployment rate and GDP growth give rise to a within-district 
correlation of regression model errors (Cameron and Miller 2015). ${ }^{21}$

Starting with our variables of interest, the time period indicators of the year of entry are smaller than one for both men and women during the reform period (2003-2005). For the post-reform period (2006-2008), the hazard ratio continues to be smaller than one for women but is insignificant for men. These results imply that job durations ceteris paribus are somewhat longer for new jobs started in the reform period (2003-2005) compared to the reference period (1998-2002). For men, in the years following the Hartz reforms, durations do not differ from those in the reference period, whereas for women, job durations continue to be slightly longer than those in the period preceding the Hartz reforms.

For the rest of the models, the pattern of the baseline hazard, the associations of the covariates with the hazard rate and the relevance of the frailty term are of interest as well. The pattern of the estimated risk of leaving a job is non-monotonic: the hazard ratios for the time periods at the top of the table initially slightly increase (for women, there is also a temporary decline in the third month) and then start to decrease after the first three months of employment. This non-monotonic pattern can be explained by the high initial risk of contract dissolution if a mismatch is found in combination with the stabilizing effect of job-specific human capital (Blossfeld et al. 2007, p. 121). In addition to this baseline pattern - and despite the large number of covariates - the importance of unobserved heterogeneity is confirmed in all of our models by likelihood ratio tests that are highly significant.

The results also point to a clear seasonal pattern in job durations. The estimated hazard ratios from the men's model are large and increase during the year, implying the longest durations for jobs beginning in the first three calendar months. For women, this pattern is less regular and less pronounced.

The state of the local labour market might influence job durations through fluctuations in labour demand. The respective control variables are insignificant, however. Persistent differences in economic conditions between regions might also influence job durations. The estimated hazard ratios for the federal states seem to reflect to some extent the north-south divide in Germany. The reference is North Rhine-Westphalia, which is the state with the largest population and is situated in the western centre. Significantly shorter job durations are estimated in the northern states

\footnotetext{
${ }_{21}$ As suggested by an anonymous referee, we tested an alternative model specification that includes district-level dummy variables instead of the continuous variables used in the model in Table 1. The differences between the results of these two specifications with respect to other covariates were very small. The results of the district dummy variable models are available upon request.
}

of Schleswig Holstein and Hamburg, and longer job durations are estimated in the southern states. For the state of Hesse, situated in the southern centre, and the economically strong states Baden Württemberg and Bavaria, which are both situated in the south of Germany, we find lower risks of leaving jobs and thus longer durations (in Bavaria, this is only found for women).

The effect of firm size is clear and rather large. As predicted by theories of internal labour markets, job duration monotonically increases with the size of the firm for both men and women.

For some industries, we can also note fairly strong and significant effects. Compared to business services (the reference group), jobs tend to be very stable for men in manufacturing and for women in social and public services. Very large and significant hazard ratios for both men and women are estimated for temporary agency jobs, indicating far shorter durations. Although this confirms the general notion that temporary agency jobs are of low quality, a more careful analysis would need to look at subsequent jobs to see how many temporary agency jobs lead to regular jobs (e. g., Jahn and Rosholm 2014).

Part-time jobs with a minimum of $18 \mathrm{~h}$ per week are much shorter for men but only slightly more stable for women. One interpretation of this finding is that for many men, part-time jobs are only temporary solutions until they find a full-time job. Women might have longer durations in part-time jobs, although these jobs are relatively hard to find.

Age and nationality have the expected effects: job duration is much shorter for younger age groups and foreigners. The skill effect is pronounced for both men and women. Workers for whom information on skill was missing and unskilled workers have far higher risks of leaving their jobs compared to the reference group (vocational training with at least an intermediate degree), which indicates the importance of completed vocational training in Germany. Among workers with higher educational levels, only men with a university or comparable degree have more stable jobs than the reference group. Among the categories describing previous labour market status, the reference group (job-to-job changers) ${ }^{22}$ is the largest group. Persons beginning new jobs out of unemployment form another sizeable group. Although the group of persons starting a new job after a gap is also fairly large, the group of persons in their first jobs and the group of persons who are first unemployed and then have a gap before starting their current jobs are both rather small. The results show clearly that compared to job-to-job changers, all other groups experience shorter job durations. The negative association with duration is

\footnotetext{
22 Job-to-job changers are defined as workers with at most one month of non-employment between their last job and their current job.
} 
Table 1 Job Duration Models for West Germany

\begin{tabular}{|c|c|c|c|c|}
\hline & Job duration & & & \\
\hline & Men & & Women & \\
\hline & Hazard ratio & $\mathrm{z}^{\mathrm{a}}$ & Hazard ratio & $\mathrm{z}^{\mathrm{a}}$ \\
\hline$\overline{\text { Duration }^{\mathrm{b}}}$ & & & & \\
\hline $0-31$ days & 0.802 & -171.5 & 0.936 & -197.6 \\
\hline 32-61 days & 0.923 & -190.9 & 0.988 & -195.5 \\
\hline 62-91 days & 0.905 & -198.2 & 0.893 & -194.9 \\
\hline 92-122 days & 1.039 & -192.8 & 1.036 & -205.7 \\
\hline 123-183 days & 0.906 & -186.5 & 0.878 & -223.8 \\
\hline 184-365 days & 0.877 & -190.9 & 0.793 & -232.9 \\
\hline 366-548 days & 0.733 & -173.2 & 0.676 & -229.0 \\
\hline 549-730 days & 0.728 & -162.5 & 0.652 & -203.9 \\
\hline Year of entry (ref: 1998-2002) & & & & \\
\hline $2003-2005$ & 0.897 & -9.2 & 0.916 & -7.2 \\
\hline 2006-2008 & 0.984 & -1.2 & 0.959 & -3.6 \\
\hline Quarter of entry (ref: 1st quart & & & & \\
\hline 2nd quarter & 1.320 & 21.0 & 1.212 & 14.4 \\
\hline 3rd quarter & 1.333 & 21.2 & 1.184 & 12.3 \\
\hline 4th quarter & 1.364 & 21.3 & 1.238 & 15.8 \\
\hline Local labour demand (district & & & & \\
\hline Unemployment rate & 1.002 & 0.8 & 1.000 & -0.1 \\
\hline GDP growth & 0.999 & -0.7 & 0.998 & -1.7 \\
\hline Federal state (ref: North Rhine & & & & \\
\hline Schleswig Holstein, Hamburg & 1.060 & 2.5 & 1.032 & 1.2 \\
\hline Lower Saxony, Bremen & 1.033 & 1.4 & 0.989 & -0.6 \\
\hline Hesse & 0.963 & -2.0 & 0.945 & -3.1 \\
\hline Rhineland Palatinate, Saarland & 1.050 & 2.1 & 0.961 & -1.3 \\
\hline Baden-Württemberg & 0.930 & -3.2 & 0.904 & -4.8 \\
\hline Bavaria & 1.000 & 0.0 & 0.932 & -3.4 \\
\hline Firm size (ref: $<20$ employees) & & & & \\
\hline $20-49$ & 0.813 & -14.5 & 0.966 & -2.3 \\
\hline $50-249$ & 0.680 & -28.8 & 0.914 & -6.6 \\
\hline $250-999$ & 0.538 & -31.9 & 0.779 & -13.3 \\
\hline 1000 and more & 0.460 & -19.4 & 0.659 & -13.8 \\
\hline Industry (ref: business services & & & & \\
\hline Agriculture, mining & 2.089 & 14.6 & 2.337 & 9.3 \\
\hline Energy, traffic and information & 1.098 & 3.0 & 1.017 & 0.7 \\
\hline Manufacturing & 0.751 & -11.7 & 0.918 & -4.5 \\
\hline Construction & 1.175 & 6.0 & 0.849 & -4.2 \\
\hline Trade and retail & 0.895 & -4.4 & 1.011 & 0.6 \\
\hline Personal and domestic services & 1.389 & 9.4 & 1.374 & 14.9 \\
\hline Social and public services & 0.980 & -0.9 & 0.828 & -10.5 \\
\hline Temporary work agency & 4.302 & 38.9 & 4.251 & 40.5 \\
\hline Foreigner & 1.682 & 32.8 & 1.438 & 18.5 \\
\hline Age (ref: $30-34$ ) & & & & \\
\hline Age 25-29 & 1.121 & 8.2 & 1.208 & 12.4 \\
\hline Age 35-39 & 0.955 & -3.4 & 0.856 & -11.1 \\
\hline Age $40-44$ & 0.911 & -6.0 & 0.820 & -11.6 \\
\hline
\end{tabular}


Table 1 Job Duration Models for West Germany (Continued)

\begin{tabular}{|c|c|c|c|c|}
\hline & \multicolumn{4}{|l|}{ Job duration } \\
\hline & \multicolumn{2}{|l|}{ Men } & \multicolumn{2}{|l|}{ Women } \\
\hline & Hazard ratio & $\mathrm{z}^{\mathrm{a}}$ & Hazard ratio & $\mathrm{z}^{\mathrm{a}}$ \\
\hline Age 45-49 & 0.895 & -6.1 & 0.824 & -10.6 \\
\hline Age $50-54$ & 0.908 & -5.8 & 0.828 & -10.2 \\
\hline \multicolumn{5}{|c|}{ Skill Level (ref: vocational training with at most an intermediate degree) } \\
\hline Missing information on educational level & 1.875 & 18.6 & 1.696 & 17.1 \\
\hline $\begin{array}{l}\text { No vocational training with at most an interme- } \\
\text { diate degree }\end{array}$ & 1.254 & 12.7 & 1.294 & 14.9 \\
\hline $\begin{array}{l}\text { High school/equivalent; with or without voca- } \\
\text { tional training }\end{array}$ & 1.076 & 4.3 & 1.002 & 0.1 \\
\hline $\begin{array}{l}\text { University/technical/professional college de- } \\
\text { gree }\end{array}$ & 0.823 & -11.2 & 1.036 & 2.5 \\
\hline \multicolumn{5}{|l|}{ Preceding state (ref: job-to-job) } \\
\hline First spell & 1.035 & 1.9 & 1.085 & 4.9 \\
\hline Unemployed & 1.995 & 45.1 & 1.748 & 33.6 \\
\hline Job followed by gap & 1.708 & 31.6 & 1.503 & 28.7 \\
\hline Unemployment followed by gap & 1.205 & 10.9 & 1.217 & 12.6 \\
\hline Part-time (min. 18 h/week) & 1.407 & 11.9 & 0.954 & -3.2 \\
\hline Variance of frailty term $(\log \theta)$ & -0.394 & -8.5 & -0.852 & -8.8 \\
\hline$L R$ - test for significance of $\theta$ & 1100.9 & - & 223.6 & - \\
\hline Wald chi $i^{2}$ & $1,558,412$ & - & $1,255,807$ & - \\
\hline Log likelihood & $-218,031$ & - & $-173,214$ & - \\
\hline Number of obs. & 180,546 & - & 142,335 & - \\
\hline
\end{tabular}

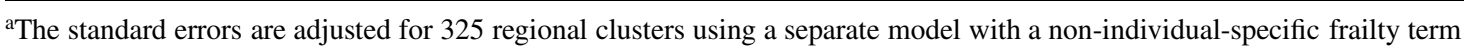

${ }^{\mathrm{b}}$ The hazard ratios of the duration time pieces are multiplied by 1000 in order to obtain legible values

Source: IEB, Federal Statistical Office, own calculations

strongest for persons who are unemployed immediately before starting a job.

\subsubsection{Wages}

As in the duration model, we use one randomly selected employment spell per person beginning in the period 1998 to 2009. We estimate the models separately for men and women in West Germany (see Table 2). ${ }^{23}$

Once again, the coefficients ${ }^{24}$ of the time period indicators are of central interest. They are negative for the reform period (2003-2005) and for the period following the Hartz reforms (2006-2009), indicating that real wages have been falling since the reference period. Although we control for cyclical effects by including GDP growth rates, an ad-

23 Once again, the difference between the number of observations used to produce Fig. 5 and 6 and the number of observations used in the wage model follows from the selection of only one spell per person and from the exclusion of spells starting in the final year, 2010. Descriptive information on the variables of the wage model is contained in Table 9 in the appendix.

24 As a rule of thumb, small coefficients $(<0.05)$ indicate percentage wage changes associated with a unit change in the respective covariate. For larger coefficients, this rule becomes inaccurate. ditional wage effect of the great recession in 2008/2009 cannot be excluded. The negative wage effect during the reform period is slightly stronger for women than for men; in the post-reform period, we observe much lower entry wages for both sexes. The skill level has the expected positive effect on wages.

Potential work experience has a significant effect only for men. The wages of foreigners are approximately $8 \%$ lower for women and more than $10 \%$ lower for men.

The preceding labour market status is highly relevant for wages in newly started jobs. There is a large negative wage differential for workers in their first job following unemployment. The estimated coefficients are -0.268 (men) and -0.228 (women), which correspond to percentage wage losses of $20 \%$ or more compared to the reference wages of job-to-job changers.

Given the size of these coefficients, it should be stressed once again that these results are descriptive and do not reflect causal relationships. ${ }^{25}$

\footnotetext{
${ }^{25}$ Schmieder et al. (2016) estimate a causal effect of unemployment on wages. The effect is found to be significantly negative and large, with an additional month of unemployment corresponding to a reduction in the reemployment wage of $0.8 \%$.
} 
Table 2 Wage Models for West Germany

\begin{tabular}{|c|c|c|c|c|}
\hline & Censored $\mathrm{Re}$ & del & & \\
\hline & Log Real W & & & \\
\hline & Men & & Women & \\
\hline & Coefficient & $\mathrm{z}^{\mathrm{a}}$ & Coefficient & $\mathrm{z}^{\mathrm{a}}$ \\
\hline Year of entry (ref: 1998-2002) & & & & \\
\hline $2003-2005$ & -0.023 & -5.7 & -0.030 & -5.5 \\
\hline 2006-2009 & -0.089 & -29.8 & -0.088 & -20.1 \\
\hline Skill level (ref: vocational training with at most an in & mediate degre & & & \\
\hline Missing information on educational level & -0.205 & -11.1 & -0.174 & -11.3 \\
\hline $\begin{array}{l}\text { No vocational training with at most an intermediate } \\
\text { degree }\end{array}$ & -0.220 & -38.4 & -0.217 & -23.3 \\
\hline $\begin{array}{l}\text { High school/equivalent; with or without vocational } \\
\text { training }\end{array}$ & 0.096 & 17.7 & 0.148 & 22.0 \\
\hline University/technical/professional college degree & 0.495 & 52.6 & 0.413 & 44.2 \\
\hline Potential experience $^{\mathrm{b}}$ & 3.582 & 27.1 & 0.044 & 0.3 \\
\hline Potential experience squared $^{\mathrm{b}}$ & -0.063 & -23.2 & 0.006 & 1.8 \\
\hline Preceding state (ref: job-to-job) & & & & \\
\hline First spell & 0.024 & 5.7 & -0.014 & -2.4 \\
\hline Unemployed & -0.268 & -48.4 & -0.228 & -37.6 \\
\hline Job followed by gap & -0.179 & -34.4 & -0.190 & -31.9 \\
\hline Unemployment followed by gap & -0.179 & -29.9 & -0.198 & -28.3 \\
\hline Local labour demand (district level) & & & & \\
\hline Unemployment rate & -0.002 & -2.1 & 0.003 & 2.2 \\
\hline GDP growth & 0.035 & 0.8 & 0.067 & 0.8 \\
\hline Federal state (ref: North Rhine-Westphalia) & & & & \\
\hline Schleswig Holstein, Hamburg & -0.023 & -1.4 & 0.021 & 0.7 \\
\hline Lower Saxony, Bremen & -0.048 & -6.7 & -0.063 & -3.2 \\
\hline Hesse & 0.011 & 0.6 & 0.045 & 1.6 \\
\hline Rhineland Palatinate, Saarland & -0.049 & -4.4 & -0.048 & -2.8 \\
\hline Baden-Württemberg & 0.017 & 1.6 & 0.017 & 1.0 \\
\hline Bavaria & 0.008 & 0.5 & 0.038 & 1.1 \\
\hline Firm size (ref: < 20 employees) & & & & \\
\hline $20-49$ & 0.128 & 34.1 & 0.176 & 31.3 \\
\hline $50-249$ & 0.181 & 37.1 & 0.268 & 49.2 \\
\hline $250-999$ & 0.270 & 45.8 & 0.395 & 50.1 \\
\hline 1000 and more & 0.363 & 37.2 & 0.511 & 31.4 \\
\hline Industry (ref: business services) & & & & \\
\hline Agriculture, mining & -0.221 & -13.1 & -0.174 & -7.8 \\
\hline Energy, traffic and information & -0.123 & -8.8 & -0.010 & -0.4 \\
\hline Manufacturing & 0.007 & 0.8 & -0.035 & -2.8 \\
\hline Construction & 0.005 & 0.5 & -0.173 & -8.0 \\
\hline Trade and retail & -0.035 & -4.3 & -0.051 & -3.7 \\
\hline Personal and domestic services & -0.359 & -32.0 & -0.247 & -21.3 \\
\hline Social and public services & -0.164 & -13.3 & -0.006 & -0.3 \\
\hline Temporary work agency & -0.543 & -43.2 & -0.405 & -31.5 \\
\hline
\end{tabular}


Table 2 Wage Models for West Germany (Continued)

\begin{tabular}{|c|c|c|c|c|}
\hline & Censored $\mathrm{R}$ & del & & \\
\hline & Log Real W & & & \\
\hline & Men & & Women & \\
\hline & Coefficient & $\mathrm{z}^{\mathrm{a}}$ & Coefficient & $\mathrm{z}^{\mathrm{a}}$ \\
\hline Foreigner & -0.153 & -29.4 & -0.080 & -9.4 \\
\hline Constant & 4.017 & 270.0 & 3.941 & 209.9 \\
\hline $\log ($ sigma $)$ & -0.863 & -65.6 & -0.699 & 0.7 \\
\hline Wald chi ${ }^{2}(33)$ & 39.685 & - & 38.019 & - \\
\hline Log pseudolikelihood & -105.077 & - & -72.515 & - \\
\hline Number of obs. & 178,065 & - & 99,012 & - \\
\hline Censored obs. & 17,278 & - & 2827 & - \\
\hline
\end{tabular}

The standard errors of the coefficients are adjusted for 325 regional clusters

${ }^{b}$ The coefficients of the experience variables and of GDP growth are multiplied by 100 in order to obtain legible values

Source: IEB, Federal Statistical Office, own calculations

The coefficient of the local unemployment rate is negative in the model for men's wages and positive in the model for women's wages. ${ }^{26}$ The effects of the federal states variables are often insignificant, with persons from Lower Saxony/Bremen and Rhineland Palatinate/Saarland having significantly lower wages than those from the reference state of North Rhine-Westphalia.

Firm size is positively correlated with wages; larger firms pay higher wages. This effect seems to be stronger for women. In most industries, wages are lower than in business services, which is the reference group. In particular, workers in personal and domestic services and temporary agency workers are worse off.

\subsubsection{Summary of results for job duration and wages}

In summary, the results of the multivariate analysis presented in this section show that ceteris paribus, the durations of new jobs did not significantly decrease either during or after the Hartz reform period compared to the previous period (1998-2002) and that there were real wage losses during the reform period and even greater wage losses in the period following the Hartz reforms.

\subsection{Job durations and wages for selected groups of workers over time}

Because our analysis is concerned with increasing inequality, it might be worthwhile to check whether the situations of certain groups of workers known to be disadvantaged have improved or worsened over time. We select three

26 The positive sign in the model for women is somewhat surprising, but because we do not estimate a causal model, this result may simply be a spurious relationship resulting from changes in the supply of female labour and associated positive wage changes during our observation period. An anonymous referee brought this issue to our attention. groups - temporary agency workers, workers who were unemployed before starting a new job, and unskilled workers - to determine whether trends for them differ from the overall trends assessed previously.

In Fig. 7, similar to Sect. 4.1, Kaplan-Meier survivor functions are plotted across periods for the entire sample (first panel) and for the groups of temporary agency workers, unskilled workers, and previously unemployed workers.

It is obvious that there is virtually no effect on job durations for these groups over time. Comparing the survivor functions of these three groups with that of the entire sample confirms the lower level of job stability for the selected groups, especially for temporary agency workers. ${ }^{27}$

Table 3 presents median log wages together with changes across time periods for the entire sample and for the three selected groups of workers. The model analysis in Sect. 4.2.2 clearly proved that these groups have lower wages ceteris paribus, and the median wages complement this finding. For all men, the median wage dropped by $3 \%$ from the first to the second period and further declined by approximately $9 \%$ from the second to the third period. For women, the decline between the first two periods is also approximately $3 \%$ and the decline between the second and the third periods is approximately $4 \%$.

Temporary agency workers, the group with the lowest median wage, experienced sizable wage losses between the first two periods: the median wage dropped by approximately $6 \%$ for men and more than $10 \%$ for females. Unskilled workers as a group clearly suffered the largest wage losses: for men, the median wage falls by approximately $8 \%$ between the first two periods and falls again by more than $10 \%$ between the second and third periods. The median wage of female unskilled workers falls by ap-

\footnotetext{
27 We also tried to assess the question of different group trends by estimating models in which all covariates were interacted with the time period indicators. These results are available upon request.
} 
Table 3 Median Wages for Different Groups (Source: IEB, own calculations)

\begin{tabular}{|c|c|c|c|c|c|c|}
\hline & & \multicolumn{3}{|c|}{ Log Median Wage } & \multicolumn{2}{|l|}{ Differences } \\
\hline & & 1998-2002 & 2003-2005 & 2006-2010 & 03/05-98/02 & 06/10-03/05 \\
\hline \multirow[t]{4}{*}{$\overline{\text { Men }}$} & All & 4.36 & 4.33 & 4.24 & -0.03 & -0.09 \\
\hline & Temporary & 3.81 & 3.75 & 3.71 & -0.06 & -0.04 \\
\hline & Unskilled & 4.03 & 3.95 & 3.84 & -0.08 & -0.12 \\
\hline & Unempl. before & 4.19 & 4.16 & 4.05 & -0.03 & -0.12 \\
\hline \multirow[t]{4}{*}{ Women } & All & 4.14 & 4.11 & 4.06 & -0.03 & -0.04 \\
\hline & Temporary & 3.75 & 3.64 & 3.63 & -0.11 & -0.01 \\
\hline & Unskilled & 3.83 & 3.77 & 3.69 & -0.06 & -0.08 \\
\hline & Unempl. before & 3.99 & 3.93 & 3.87 & -0.06 & -0.06 \\
\hline
\end{tabular}

$N=761,246$

proximately $6 \%$ between the first and second periods and by approximately $8 \%$ between the second and the third periods. For men who were unemployed before starting the current job, there is also a very sharp decline in the median wage between the last two periods. For the group of women starting a job after unemployment, the drop in the median wage is approximately $6 \%$ both between the first two periods and between the last two periods.

It is reasonable to consider overlaps between these groups of disadvantaged workers (e.g., workers who are both unskilled and employed in a temporary work agency) and to examine the median wages of these overlap groups across periods. However, jobs with workers belonging to two or more of our disadvantaged groups account for less than $10 \%$ of the sample, and there are only a few subgroups for which the wage trends were even worse than those reported in Table $3 .^{28}$

In summary, median wage losses were often larger in the three selected groups compared to overall wage trends. ${ }^{29}$ The sizable wage losses observed for jobs held by disadvantaged groups of workers might partly reflect demand-side changes, such as changes in relative skill demand. On the supply side, the decrease in reservation wages of workers in these groups is likely linked to the changes in the benefit system, because the risk of (recurrent) unemployment for these workers is comparatively high.

\footnotetext{
${ }^{28}$ In contrast, the jobs of previously unemployed workers account for $29 \%$ of the job sample used for the descriptive analysis in Table 3 and jobs in temporary agencies - which strongly increased in number after the reform period - account for $10 \%$ of that job sample.

29 When we tried to detect these combined group-period-effects by including interaction terms in our wage model, the coefficients were often rather small and insignificant. The results are available from the authors upon request.
}

\section{Concluding remarks}

In this paper, we have assessed whether a reduction in the quality of new jobs has occurred in the German labour market during and/or after the implementation of the Hartz reform.

Our results on overall trends in job durations indicate stable job durations for men and somewhat longer durations for women. Interestingly, the graphical analysis does not show a stronger tendency towards a more unequal distribution of job durations. Consistent with the finding of decreased labour turnover, the results of the duration analysis even imply somewhat longer job durations in the reform period. When looking at selected groups of workers, we also do not find evidence of decreased job stability over time. Although job stability seems to hold steady, we confirm both a decrease in real wages over time and an increase in overall wage dispersion. For our sample of newly started jobs, several of the observed wage decreases are quite large. The estimated models reveal stronger wage losses in the period 2006-2009 compared to the reform period 2003-2005, which is due at least in part to the great recession in 2008/2009. The selected groups experienced severe wage losses in both periods, which in most cases were larger than the sizeable decrease in the overall median wage.

The predominantly high level of job stability is rather surprising. One explanation could be that the matching process has become more efficient, not only with respect to the duration of job searches but also with respect to the quality of job matches. In light of the results regarding wages, however, we attribute this stability to the higher cost of job mobility. Workers are more reluctant to quit both because the benefit system is less generous than it was previously and because entry wages are decreasing over time. Nevertheless, firms can count on very flexible labour, as demonstrated by the far shorter job durations of temporary agency workers compared to other workers. 
Fig. 7 Survivor Functions for Different Groups. a Men, b Women (Source: IEB, own calculations, $N=832,158$ ) a

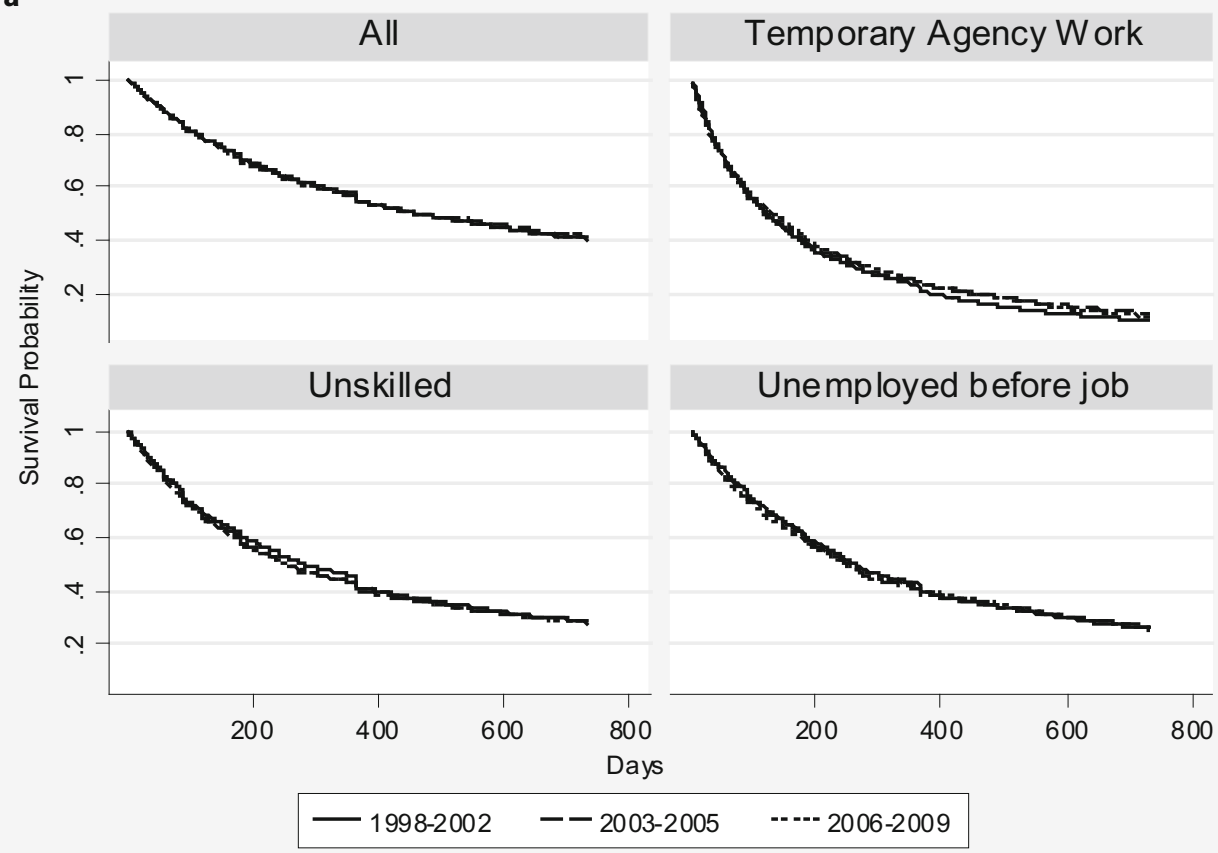

b

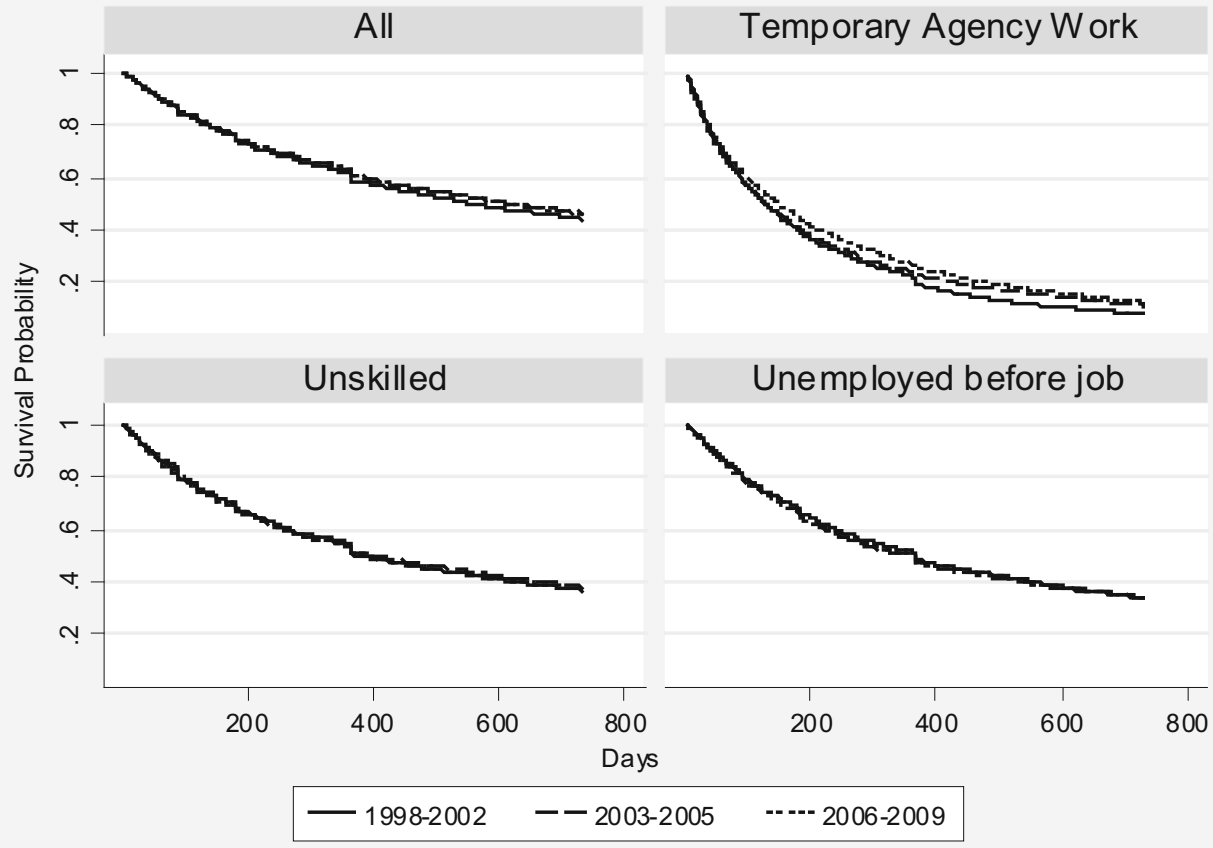


With respect to wages, it is difficult to attribute our results solely to the Hartz reforms. The decrease in real wages for our sample of new jobs begins in the years 2001/2002, well before the Hartz reforms. However, the marked wage losses for disadvantaged groups of workers indicate a strong decline in reservation wages, which is likely linked to changes in the benefit system because these workers suffer a comparatively high risk of unemployment, especially long-term unemployment.
Acknowledgements We would like to thank Johannes Ludsteck and Joseph Sakshaug and the anonymous reviewers for helpful comments and suggestions.

Open Access This article is distributed under the terms of the Creative Commons Attribution 4.0 International License (http:// creativecommons.org/licenses/by/4.0/), which permits unrestricted use, distribution, and reproduction in any medium, provided you give appropriate credit to the original author(s) and the source, provide a link to the Creative Commons license, and indicate if changes were made. 


\section{Appendix}

Fig. 8 East Germany: Job Survival Probabilities after 6, 12, 18 and 24 Months (Source: IEB, own calculations; $N=$ 248,240)

Fig. 9 East Germany: Distribution of Wages (Source: IEB, own calculations; $N=217,921$ )
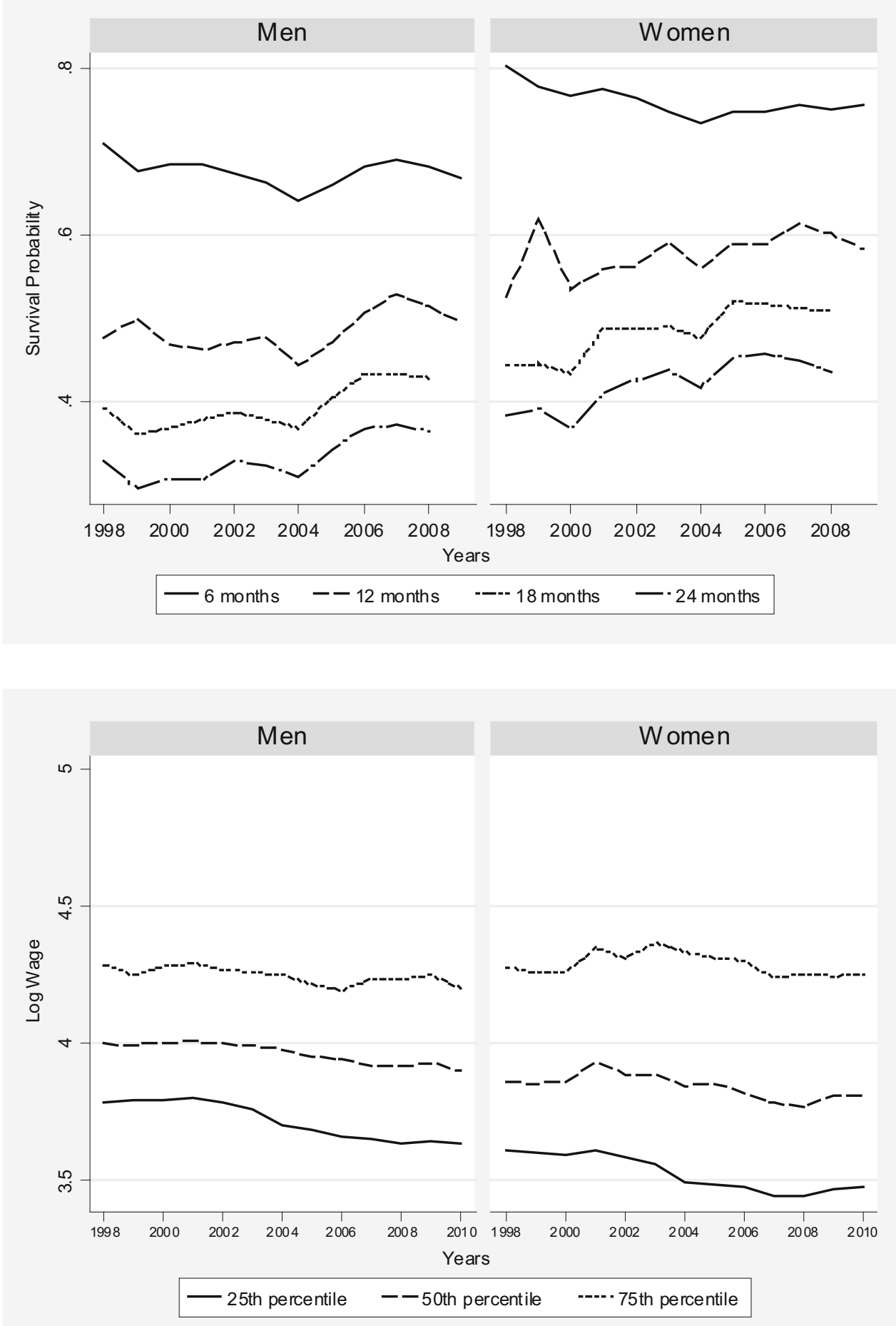
Table 4 Survival Probabilities after 6, 12, 18 and 24 Months of Duration, by Gender

\begin{tabular}{|c|c|c|c|c|c|c|c|c|}
\hline \multicolumn{9}{|c|}{ West Germany } \\
\hline - & Men & & & & Women & & & \\
\hline Year & 6 Mths & $12 \mathrm{Mths}$ & $18 \mathrm{Mths}$ & $24 \mathrm{Mths}$ & 6 Mths & $12 \mathrm{Mths}$ & 18 Mths & 24 Mths \\
\hline 1998 & 0.72 & 0.56 & 0.49 & 0.42 & 0.75 & 0.60 & 0.51 & 0.44 \\
\hline 1999 & 0.71 & 0.56 & 0.47 & 0.41 & 0.76 & 0.62 & 0.52 & 0.46 \\
\hline 2000 & 0.70 & 0.55 & 0.46 & 0.39 & 0.73 & 0.59 & 0.49 & 0.42 \\
\hline 2001 & 0.71 & 0.55 & 0.47 & 0.39 & 0.75 & 0.59 & 0.51 & 0.44 \\
\hline 2002 & 0.70 & 0.54 & 0.46 & 0.40 & 0.74 & 0.59 & 0.51 & 0.45 \\
\hline 2003 & 0.71 & 0.56 & 0.47 & 0.41 & 0.76 & 0.62 & 0.53 & 0.46 \\
\hline 2004 & 0.71 & 0.55 & 0.47 & 0.41 & 0.75 & 0.62 & 0.53 & 0.46 \\
\hline 2005 & 0.71 & 0.55 & 0.48 & 0.42 & 0.76 & 0.62 & 0.54 & 0.47 \\
\hline 2006 & 0.70 & 0.55 & 0.47 & 0.40 & 0.75 & 0.62 & 0.53 & 0.46 \\
\hline 2007 & 0.70 & 0.57 & 0.47 & 0.41 & 0.75 & 0.62 & 0.53 & 0.46 \\
\hline 2008 & 0.70 & 0.55 & 0.47 & 0.41 & 0.76 & 0.62 & 0.53 & 0.46 \\
\hline 2009 & 0.70 & 0.54 & - & - & 0.76 & 0.61 & - & - \\
\hline \multicolumn{9}{|c|}{ East Germany } \\
\hline - & Men & & & & Women & & & \\
\hline Year & 6 Mths & $12 \mathrm{Mths}$ & $18 \mathrm{Mths}$ & $24 \mathrm{Mths}$ & 6 Mths & $12 \mathrm{Mths}$ & $18 \mathrm{Mths}$ & $24 \mathrm{Mths}$ \\
\hline 1998 & 0.71 & 0.48 & 0.39 & 0.33 & 0.80 & 0.53 & 0.44 & 0.38 \\
\hline 1999 & 0.68 & 0.50 & 0.36 & 0.29 & 0.78 & 0.62 & 0.45 & 0.39 \\
\hline 2000 & 0.68 & 0.47 & 0.37 & 0.31 & 0.77 & 0.53 & 0.43 & 0.37 \\
\hline 2001 & 0.69 & 0.46 & 0.38 & 0.30 & 0.78 & 0.56 & 0.49 & 0.41 \\
\hline 2002 & 0.68 & 0.47 & 0.39 & 0.33 & 0.77 & 0.56 & 0.49 & 0.43 \\
\hline 2003 & 0.66 & 0.48 & 0.38 & 0.32 & 0.75 & 0.59 & 0.49 & 0.44 \\
\hline 2004 & 0.64 & 0.44 & 0.37 & 0.31 & 0.73 & 0.56 & 0.48 & 0.42 \\
\hline 2005 & 0.66 & 0.47 & 0.40 & 0.34 & 0.75 & 0.59 & 0.52 & 0.45 \\
\hline 2006 & 0.68 & 0.51 & 0.43 & 0.37 & 0.75 & 0.59 & 0.52 & 0.46 \\
\hline 2007 & 0.69 & 0.53 & 0.43 & 0.37 & 0.76 & 0.61 & 0.51 & 0.45 \\
\hline 2008 & 0.68 & 0.51 & 0.43 & 0.36 & 0.75 & 0.60 & 0.51 & 0.44 \\
\hline 2009 & 0.67 & 0.50 & - & - & 0.76 & 0.58 & - & - \\
\hline
\end{tabular}

Source: IEB, own calculations

Table 5 Job Survival Probabilities after 6, 12, 18 and 24 Months of Duration, by Skill Level

\begin{tabular}{|c|c|c|c|c|c|c|c|c|c|c|c|c|}
\hline \multicolumn{13}{|c|}{ West Germany } \\
\hline \multirow[b]{2}{*}{ Year } & \multicolumn{4}{|c|}{ Unskilled } & \multicolumn{4}{|l|}{ Skilled } & \multicolumn{4}{|c|}{ Highly Skilled } \\
\hline & 6 Mths & 12 Mths & $18 \mathrm{Mths}$ & 24 Mths & 6 Mths & 12 Mths & $18 \mathrm{Mths}$ & 24 Mths & $6 \mathrm{Mths}$ & 12 Mths & 18 Mths & 24 Mths \\
\hline 1998 & 0.65 & 0.47 & 0.40 & 0.33 & 0.72 & 0.56 & 0.48 & 0.41 & 0.84 & 0.71 & 0.62 & 0.53 \\
\hline 1999 & 0.67 & 0.50 & 0.40 & 0.34 & 0.72 & 0.57 & 0.48 & 0.42 & 0.82 & 0.68 & 0.57 & 0.50 \\
\hline 2000 & 0.63 & 0.45 & 0.36 & 0.30 & 0.71 & 0.56 & 0.46 & 0.40 & 0.81 & 0.67 & 0.56 & 0.48 \\
\hline 2001 & 0.63 & 0.45 & 0.37 & 0.30 & 0.72 & 0.56 & 0.48 & 0.41 & 0.82 & 0.67 & 0.58 & 0.50 \\
\hline 2002 & 0.63 & 0.43 & 0.36 & 0.30 & 0.71 & 0.55 & 0.48 & 0.41 & 0.80 & 0.66 & 0.58 & 0.51 \\
\hline 2003 & 0.63 & 0.48 & 0.37 & 0.32 & 0.72 & 0.57 & 0.48 & 0.42 & 0.81 & 0.69 & 0.59 & 0.52 \\
\hline 2004 & 0.63 & 0.46 & 0.38 & 0.33 & 0.72 & 0.57 & 0.48 & 0.42 & 0.80 & 0.68 & 0.59 & 0.52 \\
\hline 2005 & 0.62 & 0.44 & 0.38 & 0.32 & 0.72 & 0.57 & 0.50 & 0.43 & 0.81 & 0.67 & 0.59 & 0.51 \\
\hline 2006 & 0.63 & 0.47 & 0.38 & 0.33 & 0.71 & 0.56 & 0.48 & 0.41 & 0.81 & 0.68 & 0.59 & 0.51 \\
\hline 2007 & 0.61 & 0.47 & 0.37 & 0.32 & 0.71 & 0.57 & 0.48 & 0.42 & 0.81 & 0.69 & 0.59 & 0.52 \\
\hline 2008 & 0.59 & 0.43 & 0.35 & 0.30 & 0.71 & 0.56 & 0.48 & 0.41 & 0.82 & 0.70 & 0.61 & 0.53 \\
\hline 2009 & 0.64 & 0.46 & - & - & 0.71 & 0.56 & - & - & 0.82 & 0.67 & - & - \\
\hline
\end{tabular}

Source: IEB, own calculations 
Table 6 Percentiles of the Wage Distribution and Changes, 1998 and 2010, by Gender

\begin{tabular}{|c|c|c|c|c|c|c|}
\hline \multicolumn{7}{|l|}{ West Germany } \\
\hline \multirow[t]{2}{*}{ Percentiles } & 1998 & & & 2010 & & \\
\hline & 25 th percentile & 50th percentile & 75th percentile & 25th percentile & 50th percentile & 75 th percentile \\
\hline Men & 4.09 & 4.36 & 4.66 & 3.84 & 4.19 & 4.55 \\
\hline Women & 3.78 & 4.13 & 4.45 & 3.66 & 4.05 & 4.44 \\
\hline \multirow{2}{*}{$\begin{array}{l}\text { Differences (log } \\
\text { points) }\end{array}$} & 1998 & & 2010 & & 2010-1998 & 2010-1998 \\
\hline & $\begin{array}{l}50 \text { th-25th per- } \\
\text { centile }\end{array}$ & $\begin{array}{l}75 \text { th-50th per- } \\
\text { centile }\end{array}$ & $\begin{array}{l}50 \text { th- } 25 \text { th per- } \\
\text { centile }\end{array}$ & $\begin{array}{l}75 \text { th-50th per- } \\
\text { centile }\end{array}$ & $\begin{array}{l}50 \text { th- } 25 \text { th per- } \\
\text { centile }\end{array}$ & $\begin{array}{l}75 \text { th }-50 \text { th per- } \\
\text { centile }\end{array}$ \\
\hline Men & 0.27 & 0.30 & 0.35 & 0.36 & 0.08 & 0.06 \\
\hline Women & 0.35 & 0.32 & 0.39 & 0.39 & 0.04 & 0.06 \\
\hline \multicolumn{7}{|l|}{ East Germany } \\
\hline \multirow[t]{2}{*}{ Percentiles } & 1998 & & & 2010 & & \\
\hline & 25 th percentile & 50th percentile & 75th percentile & 25 th percentile & 50th percentile & 75 th percentile \\
\hline Men & 3.78 & 4.00 & 4.29 & 3.64 & 3.90 & 4.20 \\
\hline Women & 3.61 & 3.86 & 4.28 & 3.48 & 3.81 & 4.25 \\
\hline \multirow{2}{*}{$\begin{array}{l}\text { Differences (log } \\
\text { points) }\end{array}$} & 1998 & & 2010 & & 2010-1998 & 2010-1998 \\
\hline & $\begin{array}{l}\text { 50th-25th per- } \\
\text { centile }\end{array}$ & $\begin{array}{l}75 \text { th-50th per- } \\
\text { centile }\end{array}$ & $\begin{array}{l}50 \text { th- } 25 \text { th per- } \\
\text { centile }\end{array}$ & $\begin{array}{l}75 \text { th-50th per- } \\
\text { centile }\end{array}$ & $\begin{array}{l}50 \text { th-25th per- } \\
\text { centile }\end{array}$ & $\begin{array}{l}75 \text { th }-50 \text { th per- } \\
\text { centile }\end{array}$ \\
\hline Men & 0.21 & 0.29 & 0.27 & 0.30 & 0.05 & 0.01 \\
\hline Women & 0.25 & 0.42 & 0.33 & 0.44 & 0.08 & 0.02 \\
\hline
\end{tabular}

Source: IEB, own calculations

Table 7 Percentiles of the Wage Distribution and Changes, 1998 and 2010, by Skill Level

\begin{tabular}{|c|c|c|c|c|c|c|}
\hline \multicolumn{7}{|c|}{ West Germany } \\
\hline \multirow[t]{2}{*}{ Percentiles } & \multicolumn{3}{|l|}{1998} & \multicolumn{3}{|l|}{2010} \\
\hline & $\begin{array}{l}\text { 25th per- } \\
\text { centile }\end{array}$ & $\begin{array}{l}\text { 50th per- } \\
\text { centile }\end{array}$ & $\begin{array}{l}\text { 75th per- } \\
\text { centile }\end{array}$ & 25th percentile & $\begin{array}{l}\text { 50th per- } \\
\text { centile }\end{array}$ & $\begin{array}{l}\text { 75th per- } \\
\text { centile }\end{array}$ \\
\hline Unskilled & 3.69 & 3.98 & 4.26 & 3.51 & 3.75 & 4.08 \\
\hline Skilled & 3.98 & 4.26 & 4.50 & 3.76 & 4.10 & 4.40 \\
\hline Highly Skilled & 4.49 & 4.79 & 1 & 4.23 & 4.63 & 4.99 \\
\hline \multirow[t]{2}{*}{ Differences (log points) } & 1998 & & 2010 & & 2010-1998 & 2010-1998 \\
\hline & $\begin{array}{l}\text { 50th-25th per- } \\
\text { centile }\end{array}$ & $\begin{array}{l}\text { 75th-50th per- } \\
\text { centile }\end{array}$ & $\begin{array}{l}\text { 50th-25th per- } \\
\text { centile }\end{array}$ & $\begin{array}{l}\text { 75th-50th per- } \\
\text { centile }\end{array}$ & $\begin{array}{l}50 \text { th-25th } \\
\text { percentile }\end{array}$ & $\begin{array}{l}\text { 75th-50th per- } \\
\text { centile }\end{array}$ \\
\hline Unskilled & 0.29 & 0.28 & 0.24 & 0.33 & -0.06 & 0.05 \\
\hline Skilled & 0.28 & 0.24 & 0.34 & 0.29 & 0.06 & 0.05 \\
\hline Highly Skilled & 0.30 & 1 & 0.40 & 0.36 & 0.10 & a \\
\hline
\end{tabular}

${ }^{a}$ No entry because of high proportion of censored wages. The proportion of highly skilled workers in new jobs with earnings above the social security threshold is $29 \%$ in 1998 and $17 \%$ in 2010

Source: IEB, own calculations 
Table 8 Descriptive Statistics for Job Duration Models by Gender

\begin{tabular}{|c|c|c|c|c|c|c|c|c|}
\hline \multirow[b]{3}{*}{ Time constant variables } & \multicolumn{4}{|l|}{ Men } & \multicolumn{4}{|l|}{ Women } \\
\hline & $\begin{array}{l}\text { All peri- } \\
\text { ods }\end{array}$ & 1998/02 & $2003 / 05$ & $2006 / 08$ & $\begin{array}{l}\text { All peri- } \\
\text { ods }\end{array}$ & 1998/02 & $2003 / 05$ & $2006 / 08$ \\
\hline & \multicolumn{8}{|c|}{ Relative Frequencies/Means } \\
\hline \multicolumn{9}{|l|}{ Quarter of entry } \\
\hline 1st quarter & 0.336 & 0.349 & 0.348 & 0.295 & 0.338 & 0.346 & 0.352 & 0.306 \\
\hline 2nd quarter & 0.245 & 0.243 & 0.237 & 0.258 & 0.228 & 0.232 & 0.219 & 0.227 \\
\hline 3rd quarter & 0.237 & 0.232 & 0.234 & 0.253 & 0.240 & 0.233 & 0.237 & 0.260 \\
\hline 4 th quarter & 0.182 & 0.177 & 0.181 & 0.194 & 0.194 & 0.189 & 0.192 & 0.206 \\
\hline \multicolumn{9}{|l|}{ Local labour demand $^{\mathrm{a}}$} \\
\hline \multirow[t]{2}{*}{ Unemployment rate } & 9.116 & 8.871 & 10.067 & 8.797 & 9.116 & 8.880 & 10.075 & 8.780 \\
\hline & $(3.27)$ & $(3.06)$ & $(3.32)$ & $(3.52)$ & $(3.23)$ & $(3.03)$ & $(3.28)$ & $(3.47)$ \\
\hline \multirow[t]{2}{*}{ Gdp growth } & 2.512 & 2.471 & 1.574 & 3.455 & 2.437 & 2.388 & 1.519 & 3.362 \\
\hline & (3.39) & $(3.46)$ & $(3.05)$ & $(3.27)$ & $(3.32)$ & $(3.36)$ & (2.99) & $(3.26)$ \\
\hline \multicolumn{9}{|l|}{ Federal state } \\
\hline Schleswig Holstein, Hamburg & 0.078 & 0.076 & 0.078 & 0.080 & 0.082 & 0.082 & 0.080 & 0.085 \\
\hline Lower Saxony, Bremen & 0.120 & 0.119 & 0.119 & 0.123 & 0.124 & 0.122 & 0.125 & 0.125 \\
\hline North Rhine-Westphalia & 0.277 & 0.277 & 0.283 & 0.271 & 0.267 & 0.267 & 0.271 & 0.264 \\
\hline Hesse & 0.103 & 0.104 & 0.103 & 0.101 & 0.102 & 0.101 & 0.104 & 0.100 \\
\hline Rhineland Palatinate, Saarland & 0.070 & 0.069 & 0.071 & 0.069 & 0.070 & 0.071 & 0.068 & 0.067 \\
\hline Baden-Württemberg & 0.162 & 0.164 & 0.159 & 0.161 & 0.163 & 0.165 & 0.159 & 0.163 \\
\hline Bavaria & 0.190 & 0.190 & 0.186 & 0.193 & 0.193 & 0.192 & 0.194 & 0.196 \\
\hline \multicolumn{9}{|l|}{ Firm size } \\
\hline $1-19$ & 0.305 & 0.310 & 0.312 & 0.288 & 0.326 & 0.338 & 0.323 & 0.302 \\
\hline $20-49$ & 0.157 & 0.156 & 0.157 & 0.158 & 0.144 & 0.143 & 0.147 & 0.145 \\
\hline $50-249$ & 0.276 & 0.263 & 0.277 & 0.301 & 0.274 & 0.265 & 0.275 & 0.293 \\
\hline 250-999 & 0.155 & 0.160 & 0.145 & 0.153 & 0.162 & 0.161 & 0.159 & 0.167 \\
\hline 1000 and more & 0.107 & 0.110 & 0.108 & 0.099 & 0.094 & 0.093 & 0.096 & 0.093 \\
\hline \multicolumn{9}{|l|}{ Industry } \\
\hline Agriculture, mining & 0.027 & 0.024 & 0.027 & 0.032 & 0.010 & 0.008 & 0.010 & 0.014 \\
\hline Energy, traffic and information & 0.088 & 0.090 & 0.089 & 0.085 & 0.039 & 0.040 & 0.037 & 0.038 \\
\hline Manufacturing & 0.273 & 0.291 & 0.257 & 0.250 & 0.147 & 0.161 & 0.137 & 0.125 \\
\hline Construction & 0.090 & 0.096 & 0.093 & 0.076 & 0.014 & 0.015 & 0.014 & 0.012 \\
\hline Trade and retail & 0.118 & 0.121 & 0.117 & 0.113 & 0.172 & 0.179 & 0.169 & 0.159 \\
\hline Business services & 0.161 & 0.153 & 0.164 & 0.177 & 0.179 & 0.175 & 0.177 & 0.187 \\
\hline Personal and domestic services & 0.050 & 0.050 & 0.049 & 0.050 & 0.083 & 0.084 & 0.084 & 0.081 \\
\hline Social and public services & 0.131 & 0.133 & 0.142 & 0.117 & 0.320 & 0.312 & 0.334 & 0.325 \\
\hline Temporary work agency & 0.061 & 0.043 & 0.061 & 0.101 & 0.037 & 0.026 & 0.037 & 0.060 \\
\hline Foreigner & 0.144 & 0.134 & 0.142 & 0.167 & 0.101 & 0.091 & 0.104 & 0.120 \\
\hline \multicolumn{9}{|l|}{ Age } \\
\hline Age $25-29$ & 0.220 & 0.221 & 0.197 & 0.240 & 0.216 & 0.214 & 0.204 & 0.230 \\
\hline Age $30-34$ & 0.206 & 0.234 & 0.188 & 0.160 & 0.201 & 0.224 & 0.186 & 0.163 \\
\hline Age $35-39$ & 0.191 & 0.196 & 0.198 & 0.176 & 0.196 & 0.198 & 0.207 & 0.183 \\
\hline Age $40-44$ & 0.158 & 0.143 & 0.172 & 0.176 & 0.169 & 0.160 & 0.177 & 0.184 \\
\hline
\end{tabular}


Table 8 Descriptive Statistics for Job Duration Models by Gender (Continued)

\begin{tabular}{|c|c|c|c|c|c|c|c|c|}
\hline \multirow[b]{3}{*}{ Time constant variables } & \multicolumn{4}{|l|}{ Men } & \multicolumn{4}{|l|}{ Women } \\
\hline & $\begin{array}{l}\text { All peri- } \\
\text { ods }\end{array}$ & 1998/02 & $2003 / 05$ & $2006 / 08$ & $\begin{array}{l}\text { All peri- } \\
\text { ods }\end{array}$ & 1998/02 & $2003 / 05$ & $2006 / 08$ \\
\hline & \multicolumn{8}{|c|}{ Relative Frequencies/Means } \\
\hline Age $45-49$ & 0.125 & 0.114 & 0.135 & 0.141 & 0.128 & 0.121 & 0.130 & 0.140 \\
\hline Age $50-54$ & 0.099 & 0.091 & 0.110 & 0.107 & 0.090 & 0.083 & 0.096 & 0.101 \\
\hline \multicolumn{9}{|l|}{ Skill level } \\
\hline $\begin{array}{l}\text { Missing information on educational } \\
\text { level }\end{array}$ & 0.030 & 0.027 & 0.029 & 0.039 & 0.025 & 0.023 & 0.024 & 0.028 \\
\hline $\begin{array}{l}\text { No vocational training with at most } \\
\text { an intermediate degree }\end{array}$ & 0.083 & 0.085 & 0.080 & 0.080 & 0.097 & 0.106 & 0.093 & 0.079 \\
\hline $\begin{array}{l}\text { Vocational training with at most an } \\
\text { intermediate degree }\end{array}$ & 0.579 & 0.596 & 0.578 & 0.541 & 0.574 & 0.597 & 0.565 & 0.529 \\
\hline $\begin{array}{l}\text { High school/equivalent; with or } \\
\text { without vocational training }\end{array}$ & 0.116 & 0.107 & 0.121 & 0.134 & 0.147 & 0.133 & 0.153 & 0.170 \\
\hline $\begin{array}{l}\text { University/Technical/Professional } \\
\text { College degree }\end{array}$ & 0.192 & 0.185 & 0.193 & 0.206 & 0.158 & 0.140 & 0.164 & 0.194 \\
\hline \multicolumn{9}{|l|}{ Preceding state } \\
\hline First spell & 0.161 & 0.186 & 0.145 & 0.122 & 0.139 & 0.167 & 0.120 & 0.095 \\
\hline Job-to-job & 0.351 & 0.342 & 0.350 & 0.373 & 0.340 & 0.323 & 0.352 & 0.368 \\
\hline Unemployed & 0.245 & 0.238 & 0.262 & 0.244 & 0.216 & 0.216 & 0.223 & 0.209 \\
\hline Job followed by gap & 0.126 & 0.113 & 0.134 & 0.148 & 0.184 & 0.159 & 0.205 & 0.220 \\
\hline Unemployment followed by gap & 0.116 & 0.121 & 0.108 & 0.113 & 0.121 & 0.136 & 0.101 & 0.108 \\
\hline Part-time. (min. 18 h/week) & 0.048 & 0.043 & 0.051 & 0.059 & 0.330 & 0.326 & 0.333 & 0.337 \\
\hline Number of observations & 180,546 & 97,011 & 39,793 & 43,742 & 142,335 & 76,609 & 30,945 & 34,781 \\
\hline \multicolumn{9}{|l|}{ Duration of splitted spells } \\
\hline $0-31$ days & 0.151 & 0.150 & 0.150 & 0.153 & 0.149 & 0.149 & 0.148 & 0.149 \\
\hline $32-61$ days & 0.144 & 0.144 & 0.144 & 0.146 & 0.143 & 0.143 & 0.142 & 0.143 \\
\hline 62-91 days & 0.138 & 0.138 & 0.138 & 0.139 & 0.137 & 0.137 & 0.137 & 0.137 \\
\hline 92-122 days & 0.132 & 0.132 & 0.132 & 0.133 & 0.132 & 0.133 & 0.132 & 0.133 \\
\hline 123-183 days & 0.127 & 0.127 & 0.127 & 0.127 & 0.127 & 0.127 & 0.127 & 0.127 \\
\hline 184-365 days & 0.118 & 0.119 & 0.118 & 0.117 & 0.119 & 0.120 & 0.119 & 0.119 \\
\hline 366-548 days & 0.100 & 0.100 & 0.101 & 0.099 & 0.102 & 0.101 & 0.103 & 0.102 \\
\hline 549-730 days & 0.089 & 0.090 & 0.091 & 0.086 & 0.090 & 0.090 & 0.092 & 0.089 \\
\hline Number of subspells & $1,197,088$ & 646,105 & 265,721 & 285,262 & 956,467 & 513,922 & 209,477 & 233,068 \\
\hline
\end{tabular}

a Standard deviation in parentheses

Source: IEB, Federal Statistical Office, own calculations 
Table 9 Descriptive Statistics for Wage Models by Gender

\begin{tabular}{|c|c|c|c|c|c|c|c|c|}
\hline & \multicolumn{4}{|l|}{ Men } & \multicolumn{4}{|l|}{ Women } \\
\hline & $\begin{array}{l}\text { All peri- } \\
\text { ods }\end{array}$ & 1998/02 & $2003 / 05$ & $2006 / 08$ & $\begin{array}{l}\text { All } \\
\text { periods }\end{array}$ & 1998/02 & $2003 / 05$ & $2006 / 08$ \\
\hline & \multicolumn{8}{|c|}{ Relative Frequencies/Means } \\
\hline \multicolumn{9}{|l|}{ Skill level } \\
\hline $\begin{array}{l}\text { Missing information on educational } \\
\text { level }\end{array}$ & 0.030 & 0.026 & 0.028 & 0.041 & 0.027 & 0.023 & 0.026 & 0.035 \\
\hline $\begin{array}{l}\text { No vocational training with at most } \\
\text { an intermediate degree }\end{array}$ & 0.082 & 0.085 & 0.079 & 0.078 & 0.093 & 0.106 & 0.087 & 0.074 \\
\hline $\begin{array}{l}\text { Vocational training with at most an } \\
\text { intermediate degree }\end{array}$ & 0.585 & 0.605 & 0.591 & 0.546 & 0.550 & 0.582 & 0.549 & 0.496 \\
\hline $\begin{array}{l}\text { High school/equivalent; with or } \\
\text { without vocational training }\end{array}$ & 0.113 & 0.103 & 0.114 & 0.131 & 0.159 & 0.144 & 0.163 & 0.182 \\
\hline $\begin{array}{l}\text { University/Technical/Professional } \\
\text { College degree }\end{array}$ & 0.189 & 0.181 & 0.188 & 0.204 & 0.171 & 0.146 & 0.173 & 0.213 \\
\hline Potential experience $^{a}$ & $\begin{array}{l}19.614 \\
(8.62)\end{array}$ & $\begin{array}{l}19.142 \\
(8.40)\end{array}$ & $\begin{array}{l}20.299 \\
(8.60)\end{array}$ & $\begin{array}{l}19.969 \\
(8.98)\end{array}$ & $\begin{array}{l}19.010 \\
(8.81)\end{array}$ & $\begin{array}{l}18.892 \\
(8.54)\end{array}$ & $\begin{array}{l}19.327 \\
(8.80)\end{array}$ & $\begin{array}{l}18.995 \\
(9.26)\end{array}$ \\
\hline \multicolumn{9}{|l|}{ Preceding state } \\
\hline First spell & 0.160 & 0.185 & 0.146 & 0.127 & 0.144 & 0.171 & 0.127 & 0.108 \\
\hline Job-to-job & 0.359 & 0.347 & 0.359 & 0.382 & 0.350 & 0.335 & 0.353 & 0.373 \\
\hline Unemployed & 0.243 & 0.239 & 0.263 & 0.236 & 0.221 & 0.222 & 0.230 & 0.214 \\
\hline Job followed by gap & 0.122 & 0.109 & 0.125 & 0.141 & 0.171 & 0.143 & 0.192 & 0.204 \\
\hline Unemployment followed by gap & 0.116 & 0.120 & 0.107 & 0.114 & 0.115 & 0.129 & 0.099 & 0.101 \\
\hline \multicolumn{9}{|l|}{ Local labour demand ${ }^{\mathrm{a}}$} \\
\hline Unemployment rate & $\begin{array}{l}9.027 \\
(3.24)\end{array}$ & $\begin{array}{l}8.848 \\
(3.05)\end{array}$ & $\begin{array}{l}10.034 \\
(3.32)\end{array}$ & $\begin{array}{l}8.628 \\
(3.37)\end{array}$ & $\begin{array}{l}9.018 \\
(3.21)\end{array}$ & $\begin{array}{l}8.812 \\
(3.01)\end{array}$ & $\begin{array}{l}10.042 \\
(3.26)\end{array}$ & $\begin{array}{l}8.670 \\
(3.37)\end{array}$ \\
\hline Gdp growth & $\begin{array}{l}2.092 \\
(3.71)\end{array}$ & $\begin{array}{l}2.490 \\
(3.47)\end{array}$ & $\begin{array}{l}1.580 \\
(3.06)\end{array}$ & $\begin{array}{l}1.746 \\
(4.40)\end{array}$ & $\begin{array}{l}2.022 \\
(3.61)\end{array}$ & $\begin{array}{l}2.422 \\
(3.36)\end{array}$ & $\begin{array}{l}1.497 \\
(2.94)\end{array}$ & $\begin{array}{l}1.693 \\
(4.31)\end{array}$ \\
\hline \multicolumn{9}{|l|}{ Federal state } \\
\hline Schleswig Holstein, Hamburg & 0.077 & 0.075 & 0.077 & 0.079 & 0.083 & 0.081 & 0.083 & 0.085 \\
\hline Lower Saxony, Bremen & 0.120 & 0.118 & 0.120 & 0.123 & 0.115 & 0.113 & 0.119 & 0.115 \\
\hline North Rhine-Westphalia & 0.278 & 0.279 & 0.281 & 0.274 & 0.273 & 0.270 & 0.278 & 0.274 \\
\hline Hesse & 0.102 & 0.102 & 0.104 & 0.101 & 0.100 & 0.101 & 0.101 & 0.099 \\
\hline Rhineland Palatinate, Saarland & 0.070 & 0.070 & 0.070 & 0.070 & 0.068 & 0.070 & 0.066 & 0.067 \\
\hline Baden-Württemberg & 0.163 & 0.165 & 0.160 & 0.163 & 0.165 & 0.168 & 0.160 & 0.164 \\
\hline Bavaria & 0.191 & 0.192 & 0.189 & 0.192 & 0.196 & 0.197 & 0.194 & 0.196 \\
\hline \multicolumn{9}{|l|}{ Firm size } \\
\hline $1-19$ & 0.306 & 0.309 & 0.318 & 0.293 & 0.350 & 0.356 & 0.354 & 0.335 \\
\hline $20-49$ & 0.158 & 0.156 & 0.160 & 0.161 & 0.148 & 0.147 & 0.148 & 0.151 \\
\hline
\end{tabular}


Table 9 Descriptive Statistics for Wage Models by Gender (Continued)

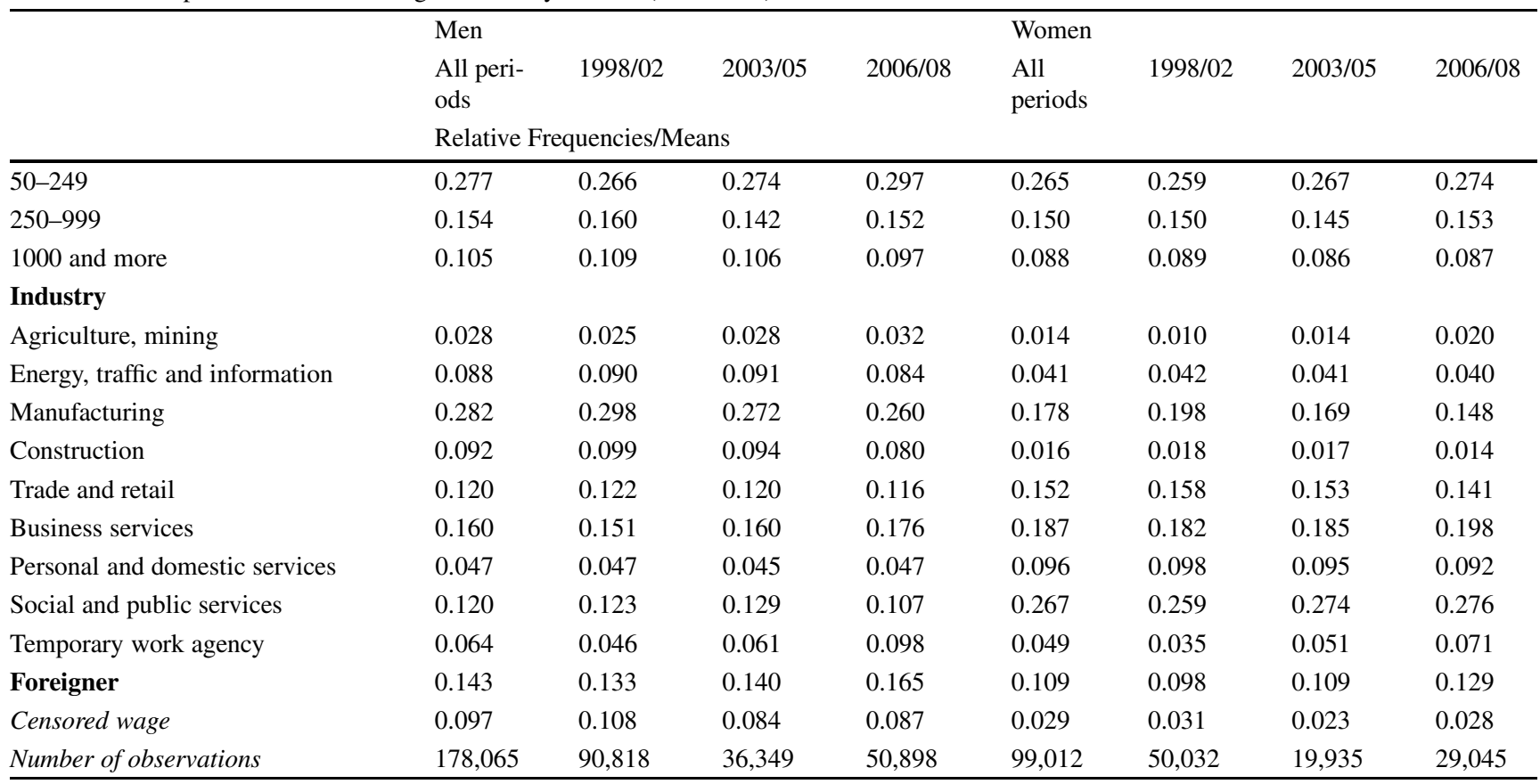

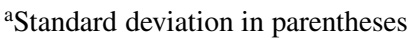

Source: IEB, Federal Statistical office, own calculations

\section{References}

Antonczyk, D., Fitzenberger, B., Sommerfeld, K.: Rising wage inequality, the decline of collective bargaining, and the gender wage gap. Labour Econ 17(5), 835-847 (2010)

Antoni, M., Jahn, E.J.: Do changes in regulation affect employment duration in temporary help agencies? Ind Labor Relat Rev 62(2), 226-251 (2009)

Arent, S., Nagl, W.: Unemployment compensation and wages: evidence from the German Hartz reforms. Jahrb Natl Okon Stat 233(4), 450-466 (2013)

Autor, D.H., Katz, L.F., Kearney, M.S.: The polarization of the US labor market. Am Econ Rev 96(2), 189-194 (2006)

Autor, D.H., Katz, L.F., Kearney, M.S.: Trends in U.S. wage inequality: revising the revisionists. Rev Econ Stat 90(2), 300-323 (2008)

Bauer, T.K., Bender, S., Bonin, H.: Dismissal protection and worker flows in small establishments. Economica 74, 804-821 (2007)

Van den Berg, G.J., Vikström, J.: Monitoring job offer decisions, punishment, exit to work, and job quality. Scand J Econ 116(2), 284-334 (2014)

Bergemann, A., Mertens, A.: Job stability trends, lay-offs, and transitions to unemployment in West Germany. Labour 25(4), 421-446 (2011)

Blossfeld, H.-P., Golsch, K., Rohwer, G.: Event history analysis with Stata. Erlbaum, Mahwah (2007)

Boockmann, B., Steffes, S.: Workers, firms, or institutions: What determines job duration for male employees in Germany? Ind Labor Relat Rev 64(1), 109-127 (2010)

Boockmann, B., Gutknecht, D., Steffes, S.: Die Wirkung des Kündigungsschutzes auf die Stabilität "junger" Beschäftigungsverhältnisse. J Labour Mark Res 41(2/3), 347-364 (2008)

Booth, A.L., Francesconi, M., Garcia-Serrano, C.: Job tenure and job mobility in Britain. Ind Labor Relat Rev 53(1), 43-70 (1999)
Bundesagentur für Arbeit: Neue Ergebnisse zu sozialversicherungspflichtig beschäftigten Arbeitslosengeld-II-Beziehern in Vollzeit und Teilzeit. Hintergrundinformation vom 28. Januar 2014 (2014)

Caliendo, M., Tatsiramos, K., Uhlendorff, A.: Benefit duration, unemployment duration and job match quality: a regression-discontinuity approach. J Appl Econom 28(4), 604-627 (2013)

Cameron, A.C., Miller, D.L.: A practitioner's guide to cluster - robust inference. J Hum Resour 50(2), 317-372 (2015)

Cameron, A.C., Trivedi, P.K.: Microeconometrics: methods and applications. Cambridge University Press, New York (2005)

Card, D., Heining, J., Kline, P.: Workplace heterogeneity and the rise of West German wage inequality. Q J Econ 128(3), 967-1015 (2013)

Cornelißen, T., Hübler, O.: Unobserved individual and firm heterogeneity in wage and job-duration functions: evidence from German linked employer-employee data. Ger Econ Rev 12(4), 469-489 (2011)

Dustmann, C., Ludsteck, J., Schönberg, U.: Revisiting the German wage structure. Q J Econ 124(2), 843-881 (2009)

Dustmann, C., Fitzenberger, B., Schönberg, U., Spitz-Oener, A.: From sick man of Europe to economic superstar. J Econ Perspect 28(1), 167-188 (2014)

Eberle, J., Jacobebbinghaus, P., Ludsteck, J., Witter, J.: Generation of time-consistent industry codes in the face of classification changes * Simple heuristic based on the Establishment History Panel (BHP). FDZ Methodenrep 05/2011 (en), Nürnberg, $21 \mathrm{~S}$, (2011)

Eichhorst, W., Tobsch, V.: Not so standard anymore? Employment duality in Germany. J Labour Mark Res 48(2), 81-95 (2015)

Fahr, R., Sunde, U.: Did the Hartz reforms speed-up the matching process? A macro-evaluation using empirical matching functions. Ger Econ Rev 10(3), 284-316 (2009)

Fleckenstein, T.: Restructuring welfare for the unemployed: the Hartz legislation in germany. J Eur Soc Policy 18(2), 177-188 (2008) 
Gartner, H., Merkl, C.: The roots of the german miracle (2011). VoxEU.org/article/roots-german-miracle (Created 9 Mar 2011). Accessed: 7. september 2016

Giannelli, G.C., Jaenichen, U., Villosio, C.: Have labor market reforms at the turn of the Millennium changed the job and employment durations of new entrants? A comparative study for Germany and Italy. J Labour Res 33(2), 143-172 (2012)

Giesecke, J., Heisig, J.P.: Labour market mobility: destabilization and destandardization: for whom? The development of West German job mobility since 1984. Schmollers Jahrb 131(2), 301-314 (2011). Proceedings of the 9th International Socio-Economic Panel User Conference

Goebel, J., Richter, M.: Nach der Einführung von Arbeitslosengeld II: Deutlich mehr Verlierer als Gewinner unter den Hilfeempfängern. DIW Wochenbericht 74(50), 753-761 (2007)

Goos, M., Manning, A.: Lousy and lovely jobs: the rising polarization of work in Britain. Rev Econ Stat 89(1), 118-133 (2007)

Goos, M., Manning, A., Salomons, A.: Job Polarization in Europe. Am Econ Rev 99(2), 58-63 (2009)

Gottschalk, P., Moffitt, R.: Changes in job instability and insecurity using monthly survey data. J Labor Econ 17(4), S91-S126 (1999)

Gutierrez, R.G.: Parametric frailty and shared frailty survival models. Stata J 2(1), 22-44 (2002)

Hertweck, M., Sigrist, O.: The aggregate effects of the Hartz reforms in Germany. SOEP papers on multidisciplinary panel data research, vol. 532. DIW, Berlin (2013)

Jacobebbinghaus, P., Seth, S.: The German integrated employment biographies sample IEBS. Schmollers Jahrb 127(2), 335-342 (2007)

Jacobi, L., Kluve, J.: Before and after the Hartz reforms: the performance of active labour market policy in Germany. J Labour Mark Res 40(1), 45-64 (2007)

Jahn, E.J., Rosholm, M.: Looking beyond the bridge: the effect of temporary agency employment on labor market outcomes. Eur Econ Rev 65, 108-125 (2014)

Jahn, E.J., Riphahn, R.T., Schnabel, C.: Feature: Flexible Forms of Employment. Boon and Bane. Econ J 122(562), F115-F124 (2012)

Klinger, S., Rothe, T.: The impact of labour market reforms and economic performance on the matching of the short-term and the long-term unemployed. Scott J Polit Econ 59(1), 90-114 (2012)

Launov, A., Wälde, K.: The employment effect of reforming a public employment agency. Eur Econ Rev 84, 140-164 (2016)

Ludsteck, J., Seth, S.: Comment on "unemployment compensation and wages: evidence from the German Hartz reforms" by Stefan Arent and Wolfgang Nagl. Jahrb Natl Okon Stat 234(5), 635-644 (2014)

Möller, J.: In the aftermath of the German labor market reforms, is there a qualitative/quantitative trade-off? Eur J Econ Econ Policies 11(2), 205-220 (2014)

Möller, J.: Did the German model survive the labor market reforms? J Labour Mark Res 48(2), 151-168 (2015)
Nekoei, A., Weber, A.: Does extending unemployment benefits improve job quality? IZA discussion paper, vol. 9034. IZA, Bonn (2015)

Osterman, P.: Introduction to the special issue on job quality: What does it mean and how might we think about it? Int Labor Relat Rev 66(4), 739-752 (2013)

Rebien, M., Kettner, A.: Die Konzessionsbereitschaft von arbeitslosen Bewerbern und Beschäftigten nach den Hartz-Reformen. WSI Mitt 64(5), 218-225 (2011)

Rhein, T.: Beschäftigungsdynamik im internationalen Vergleich: Ist Europa auf dem Weg zum "Turbo-Arbeitsmarkt"? (IABKurzbericht, 19/2010), Nürnberg, 6 S.

Riphahn, R.T., Schnitzlein, D.D.: Wage mobility in East and West Germany. Labour Econ 39, 11-34 (2016)

Rothe, T.: Arbeitsmarktentwicklung im Konjunkturverlauf: Nicht zuletzt eine Frage der Einstellungen. (IAB-Kurzbericht, 13/2009), Nürnberg, $8 \mathrm{~S}$.

Schmieder, J.F., von Wachter, T., Bender, S.: The effect of unemployment benefits and nonemployment duration on wages. Am Econ Rev 106(3), 739-777 (2016)

Gianna C. Giannelli (MSc. Economics, London School of Economics; $\mathrm{PhD}$ in Economics, European University Institute, Florence) is associate professor and member of the Department of Economics and Management at the University of Florence. She is Research Fellow of IZA (Bonn) and CHILD (Turin). She has done research on topics of Labour and Household Economics concerning youths and women in the labour market, women's and children's welfare in developing countries, intergenerational transfers, the role of domestic work in Europe. Her current research interests concern migration, remittances, education, schooling, child labour and gender. She has published on international journals like International Migration Review, Review of Economics of Education, World Development, Journal of Population Economics, Journal of Asian Economics.

Ursula Jaenichen (Dr. rer. pol., University of Hannover) is an economist and senior researcher at the Institute for Employment Research. Her research addresses topics of applied labour market analysis. She has done empirical work on the evaluation of wage subsidy programmes in Germany, on individual determinants of job durations, on aspects of data quality in survey data and in administrative data sets of the Federal Employment Agency. Results of her work have been published in Applied Economics, Journal of Labor Research, and others.

Thomas Rothe (Dr. rer. pol., University of University of ErlangenNuremberg) is senior researcher at the research department "Labour Market Processes and Institutions" of the Institute for Employment Research. His current research interests are labour market institutions and their influence on job and worker flows, job stability, unemployment and unemployment duration. He has published in Economics Letters, Labour and Scottish Journal of Political Economy. 